\title{
TRATAMENTO QUÍMICO DE UMA VERMICULITA VISANDO SEU USO EM COMPÓSITOS DE POLIPROPILENO
}

\author{
Dissertação apresentada à Escola \\ Politécnica da Universidade de São \\ Paulo para obtenção do Título de Mestre \\ em Engenharia.
}




\title{
TRATAMENTO QUÍMICO DE UMA VERMICULITA VISANDO SEU USO EM COMPÓSITOS DE POLIPROPILENO
}

\author{
Dissertação apresentada à Escola \\ Politécnica da Universidade de São \\ Paulo para obtenção do Título de Mestre \\ em Engenharia. \\ Área de concentração: \\ Engenharia Metalúrgica e de Materiais \\ Orientador: \\ Prof. Samuel Marcio Toffoli
}


Ficha Catalográfica

Peralta, Marvin Marco Chambi

Tratamento químico de uma vermiculita visando seu uso em compósitos de polipropileno / M.M.C Peralta. - -São Paulo, 2009. $64 \mathrm{p}$.

Dissertação (Mestrado) - Escola Politécnica da Universidade de São Paulo. Departamento de Engenharia Metalúrgica e de Materiais.

1. Vermiculita (Tratamento químico) 2. Materiais compósitos I. Universidade de São Paulo. Escola Politécnica. Departamento de Engenharia Metalúrgica e de Materiais II. t. 
Aprender é a única coisa de que a mente nunca se cansa, nunca tem medo e nunca se arrepende. 


\section{Agradecimentos}

Primeiramente agradeço a Deus por cada dia vivido e por ter me dado saúde e perseverança para a realização deste trabalho.

A minha família sempre presente, principalmente aos meus pais, José e Glory meus grandes amigos e principais responsáveis por quem eu sou, pela minha formação moral, profissional e em boa parte, pelas minhas expectativas. Embora distantes, sempre pude encontrar em vocês palavras de apoio e estímulo.

Ao Prof. Dr. Samuel Marcio Toffoli pela paciente orientação, amizade e apoio durante todo o processo deste trabalho.

Aos professores Antonio Carlos Vieira Coelho, Francisco Rolando Valenzuela Diaz e Helio Wiebeck pelas críticas e sugestões.

Às professoras Nicole Demarquette e Wang Shu Hui por permitir realizar parte

deste trabalho nas dependências do seus laboratórios. À Ticiane, Kleber e Walker pela ajuda no processamento dos materiais compósitos.

Ao professor Roberto Guardani por disponibilizar o granulômetro a difração laser para uso neste trabalho.

Aos companheiros do LMPSol que me ajudaram em diversos momentos durante o tempo de realização deste trabalho, pelo dia-a-dia e pela amizade.

Aos meus amigos por todo esse tempo de convívio e amizade. Aos colegas de curso e amigos que fiz neste período, cada um deles sempre será uma lembrança boa da época do mestrado.

Agradeço á Coordenadoria de Aperfeiçoamento de Pessoal de Nível Superior, (CAPES) pelo apoio financeiro que viabilizou este trabalho de mestrado

A Empresa Eucatex Ltda. por disponibilizar a amostra de vermiculita para o estudo. 


\section{Resumo}

Neste trabalho estudou-se o efeito de três diferentes tratamentos químicos utilizandose soluções aquosas de $\mathrm{LiCl}, \mathrm{NaCl}$, e $\mathrm{HCl}$ sobre o inchamento, a distribuição de tamanho de partículas e a capacidade de troca catiônica (CTC) de uma vermiculita proveniente da jazida de Paulistana, localizada no Estado do Piauí, visando seu uso em compósitos de matriz polimérica. Para os tratamentos com sais inorgânicos foram utilizadas várias concentrações de $\mathrm{LiCl}$ e $\mathrm{NaCl}$ a $90^{\circ} \mathrm{C}$ por 144 horas, permitindo a secagem da solução de tratamento. Para o tratamento ácido foram utilizadas soluções $2 \mathrm{M}$ de $\mathrm{HCl}$ à temperatura ambiente, utilizando tempos de tratamento de 2 a 10 horas. Após os tratamentos, as amostras foram submetidas a agitação mecânica intensa em dispersor de alta energia de cisalhamento (24000 RPM). Todos os tratamentos empregados resultaram em aumentos nos índices de inchamento e reduções nos tamanhos de partícula em diferentes graus. Os maiores inchamentos antes da agitação mecânica foram observados nas amostras tratadas com soluções $0,8 \mathrm{M}$ de $\mathrm{LiCl}$ sem lavagem (4 a 5 vezes a da prova em branco). Após agitação mecânica, os maiores inchamentos foram observados nas amostras tratadas com soluções $2 \mathrm{M}$ de $\mathrm{HCl}$ por 5 horas (11 vezes a da prova em branco). No entanto, após o processo de secagem não foi possível atingir-se os mesmos valores de inchamento. A diminuição mais importante no tamanho de partícula foi observada nas amostras tratadas com soluções $2 \mathrm{M}$ de $\mathrm{HCl}$ durante 5 horas, enquanto que as quedas mais significativas nos valores de CTC foram obtidas com as amostras tratadas com soluções $2 \mathrm{M}$ de $\mathrm{HCl}$ (CTC crescentes com o aumento do tempo de tratamento). Foi analisado o efeito da incorporação de vermiculita tratada acidamente em uma matriz polimérica de polipropileno (PP). A presença dessa vermiculita provocou um alto nível de degradação na matriz de PP, com a consequentemente perda de propriedades mecânicas. Esta degradação pode ser atribuída à formação de sítios ácidos nas partículas de vermiculita gerados pelo ataque do $\mathrm{HCl}$, bem como à presença de $\mathrm{HCl}$ residual da solução de tratamento.

Palavras-chave: Vermiculita. Polipropileno. Materiais compósitos poliméricos. 


\section{Abstract}

In the present work, the effect of three different chemical treatments using inorganic solutions of $\mathrm{LiCl}, \mathrm{NaCl}$, and $\mathrm{HCl}$ on the swelling, particle size distribution, and cation exchange capacity (CEC) of a vermiculite clay was studied. The clay is originary from Paulistana mine, located in the State of Piauí, Northeastern Brazil, and the final purpose of the treatment of the clay was its use in polymer-matrix composites. For the inorganic salts treatments, several solutions of $\mathrm{NaCl}$ and $\mathrm{LiCl}$ at different concentrations were used, at $90^{\circ} \mathrm{C}$ for 144 hours, allowing the treatment solution to dry out. For the acid treatment, $2 \mathrm{M} \mathrm{HCl}$ solutions at room temperature were used, using treatment times of 2 to 10 hours. After the treatments, all the samples were subjected to intense mechanical stirring in the high shear energy disperser (24000 RPM). The results showed that all treatments resulted in increases in the rates of swelling and reduction in the mean particle sizes, in different degrees. The largest swelling before mechanical stirring was observed in samples treated with solutions of $0.8 \mathrm{M} \mathrm{LiCl}$ without washing ( 4 to 5 times that of the untreated sample). After mechanical desagglomeration, the highest swelling was observed in samples treated with solutions $2 \mathrm{M} \mathrm{HCl}$ for 5 hours (11 times that of the untreated sample). However, after drying, it was no longer possible to achieve the same values of swelling. The most significant decrease in particle size was observed in samples treated with solutions $2 \mathrm{M} \mathrm{HCl}$ for 5 hours, whereas the most significant reduction in the CEC values were also obtained with the samples treated with solutions $2 \mathrm{M}$ $\mathrm{HCl}$ (CEC increasing with the time of treatment). Finally, the effect of the addition of the acid treated vermiculite to a polymeric matrix of polypropylene (PP) was examined. The evaluation of the resultant composite specimens indicated that the presence of vermiculite caused a high level of degradation of the PP matrix, with the consequent loss of mechanical properties. This degradation can be attributed to the formation of acidic sites on the vermiculite particles, generated by the direct attack of $\mathrm{HCl}$, and the presence of residual $\mathrm{HCl}$ from the treatment solution.

Keywords: Vermiculite. Polypropylene. Polymer composite materials. 


\section{Conteúdo}

\section{Lista de Figuras}

\section{Lista de Tabelas}

1 INTRODUÇÃO 1

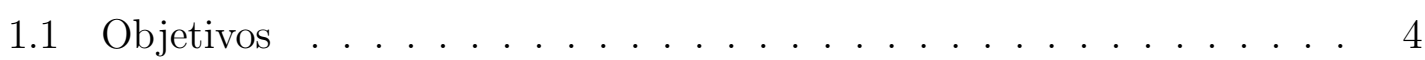

2 REVISÃO DE LITERATURA 5

2.1 Vermiculita ........................... 5

2.1.1 Capacidade de troca de cátions . . . . . . . . . . . 7

2.1.2 Produção mundial e no Brasil . . . . . . . . . . . . . . . 8

2.1.3 Usos e funções . . . . . . . . . . . . . . . . . . . . . . 10

2.2 Inchamento de argilominerais . . . . . . . . . . . . . . . . 12

2.2 .1 Inchamento cristalino . . . . . . . . . . . . 13

2.2 .2 Inchamento osmótico . . . . . . . . . . . . . 13

2.2.3 Formação e separação de agregados . . . . . . . . . . . . . . . 13

2.2.4 Desaglomeração preferencial devido ao tipo de cátion . . . . . 14

2.2.5 Inchamento de co-volume . . . . . . . . . . . . . . . 14

2.2.6 Inchamento browniano . . . . . . . . . . . . 15

2.3 Materiais compósitos . . . . . . . . . . . . . . . 15

2.3.1 Compósitos de matriz polimérica . . . . . . . . . . 16

2.4 Polipropileno . . . . . . . . . . . . . . . . . . . . . . . . . . . . . 17

2.5 Incorporação de argilominerais como cargas . . . . . . . . . . . . . . 19

2.6 Estado da arte . . . . . . . . . . . . . . . . . . . 21 
3.1 Síntese das atividades . . . . . . . . . . . . . . . . . . . . 29

3.2 Descrição dos materiais . . . . . . . . . . . . . . . . . . . 30

3.3 Técnicas de caracterização . . . . . . . . . . . . . . . . 30

3.3.1 Análise química por fluorescência de raios X (FRX) . . . . . . 30

3.3.2 Análise de difração de raios X (DRX) . . . . . . . . . . . . . 30

3.3.3 Ensaios de inchamento em água . . . . . . . . . . . . . 30

3.3.4 Determinação da capacidade de troca catiônica . . . . . . . . 32

3.3.5 Distribuição granulométrica por dispersão de laser . . . . . . . 32

3.4 Preparação do material . . . . . . . . . . . . . . . . . . . 33

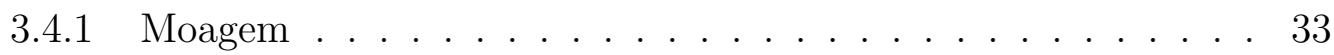

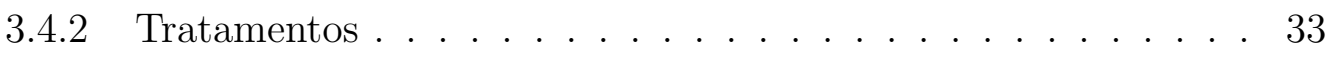

3.4.3 Agitação mecânica . . . . . . . . . . . . . . . . . 34

3.5 Preparação dos materiais compósitos . . . . . . . . . . . . . . . 34

3.5.1 Processo de mistura dos compósitos . . . . . . . . . . . 34

3.5.2 Processo de injeção dos compósitos . . . . . . . . . . . . 35

3.5.3 Análise por microscopia óptica . . . . . . . . . . . . 35

4 RESULTADOS E DISCUSSÃO 36

4.1 Caracterização da matéria-prima . . . . . . . . . . . 36

4.1.1 Análise de distribuição granulométrica . . . . . . . . . . . 36

4.1 .2 Análise química . . . . . . . . . . . . . 36

4.1.3 Difração de raios X . . . . . . . . . . . . . . 37

4.2 Avaliação dos tratamentos . . . . . . . . . . . . . . . . . . . 38

4.2.1 Ensaios de inchamento em água . . . . . . . . . . . . 38

4.2.2 Capacidade de troca catiônica . . . . . . . . . . . . . . . 40

4.2.3 Comparação dos inchamentos após a agitação mecânica . . . . 42

4.2.4 Distribuição de tamanho de partícula . . . . . . . . . . . 44 
4.3 Avaliação dos compósitos . . . . . . . . . . . . . . . . . . . . . . . 47

5 CONCLUSÕES

Anexo A - Determinação da troca de cátions pelo método de acetato de amônio

A.1 Fundamento . . . . . . . . . . . . . . . . . . 55

A.2 Material e reagentes . . . . . . . . . . . . . 55

A.3 Procedimento . . . . . . . . . . . . . . . 56

A.3.1 Determinação do amônio . . . . . . . . . . . . . . 56

A.3.2 Determinação da razão de umidade a $110^{\circ} \mathrm{C}$. . . . . . . . 56

A.4 Cálculos . . . . . . . . . . . . . . . . . . . . . . 57

Referências 


\section{Lista de Figuras}

2.1 Esquema da estrutura cristalina de uma vermiculita (GRIM, 1968) adaptado por Vieira-Coelho (1986) . . . . . . . . . . . . . . . 7

2.2 Esquema da desaglomeração preferencial devido ao tipo de cátion (LAIRD, 2006) . . . . . . . . . . . . . . . . . . . 14

3.1 Esquema de atividades . . . . . . . . . . . . . . . . . . . . . . 29

4.1 Curvas de difração da vermiculita tal como recebida e nas frações compreendidas entre as malhas s\#100 e \#250 e entre \#250 e \#325. . 37

4.2 Índices de inchamento em água para as amostras de vermiculita tratadas com diferentes concentrações de $\mathrm{LiCl}$ e $\mathrm{NaCl}$. . . . . . . . . . . . . . 38

4.3 Índices de inchamento em água para as amostras de vermiculita tratadas com HCl. . . . . . . . . . . . . . . . . . . . . . . . . 39

4.4 Índices de inchamento em água e valores de CTC para as amostras de vermiculita tratadas com $\mathrm{HCl}$. . . . . . . . . . . . . . . . . . 41

4.5 Comparação dos inchamentos das amostras de vermiculita tratadas após agitação mecânica.

4.6 Comparação do inchamento das amostras de vermiculita tratadas:

(a) Inchamento em água após o tratamento com soluções aquosas;

(b) Volume de sedimento após 24 horas a agitação mecânica; (c) Inchamento em água após a agitação mecânica e a secagem das amostras de vermiculita tratadas.

4.7 Curvas de distribuição granulométrica de amostras sem tratamentos submetidas a 10 e 20 minutos de agitação mecânica. . . . . . . . . . . . 44

4.8 Curvas de distribuição granulométrica para amostras tratadas com $\mathrm{LiCl}$ após agitação mecânica. . . . . . . . . . . . . . . . . . . . . . 45

4.9 Curvas de distribuição granulométrica para amostras tratadas com $\mathrm{NaCl}$ após agitação mecânica. 
4.10 Curvas de distribuição granulométrica para amostras tratadas com HCl após agitação mecânica. . . . . . . . . . . . . . . . . . . . . . . 46

4.11 Curvas de distribuição granulométrica das amostras tratadas com $\mathrm{LiCl}, \mathrm{NaCl}$ e HCl. . . . . . . . . . . . . . . . . . . . . . . . 47

4.12 Foto dos grânulos ou pellets dos compósitos PP/vermiculita. . . . . . 48

4.13 Foto dos corpos de prova dos compósitos PP/vermiculita. . . . . . . . 49

4.14 Micrografia das partículas de vermiculita sem tratar na matriz de PP. 50

4.15 Micrografia das partículas de vermiculita tratada acidamente na matriz de PP. . . . . . . . . . . . . . . . . . 50 50

4.16 Micrografia do compósitos contendo vermiculita sem tratar. . . . . . . 51

4.17 Micrografia do compósitos contendo vermiculita tratada acidamente. . 51 


\section{Lista de Tabelas}

2.1 Capacidade de troca de cátions dos argilominerais (BERGAYA; LAGALY; M., 2006). . . . . . . . . . . . . . . . . . 8

2.2 Principais produtores de vermiculita no mundo (POTTER, 2008). . . . 9

2.3 Reservas minerais no Brasil (CAVALCANTI, 2005). . . . . . . . . . . 9

2.4 Principais empresas produtoras no Brasil (CAVALCANTI, 2006). . . . . 10

3.1 Identificação das amostras . . . . . . . . . . . . . . . . . . 34

4.1 Composição química de vermiculitas brasileiras. . . . . . . . . . . . 37

4.2 Resultados da CTC das amostras tratadas com sais inorgânicos .. 40

4.3 Resultados da CTC das amostras tratadas com ácido clorídrico . . . . 41 


\section{INTRODUÇÃO}

O progresso tecnológico está associado à melhoria contínua das propriedades dos materiais existentes, bem como com o desenvolvimento de novos materiais que atendam requisitos específicos em termos de desempenho estrutural e funcional. Nesse sentido muitas tecnologias atuais não teriam sido possíveis sem o recurso dos novos materiais. Uma das melhores manifestações deste processo de desenvolvimento são os materiais compósitos (VASILIEV; MOROZOV, 2001).

Os compósitos poliméricos têm demonstrado características que atendem às crescentes exigências de melhor desempenho, segurança, economia e durabilidade, sendo empregados cada vez mais em substituição aos materiais monolíticos. Os compósitos poliméricos são usados numa ampla variedade de aplicações variando de eletrodomésticos a aeronáutica. A razão de seu desempenho se deve ao emprego de cargas e reforços que modificam as propriedades da resina. O aumento na demanda e rigorosas exigências de desempenho tem obrigado a identificar novos materiais para serem utilizados como cargas ou reforços em compósitos poliméricos. Como resultado a esta tendência, numerosos estudos procuram mostrar que o desempenho de produtos naturais ou resíduos industriais (fibras naturais, serragem, casca de arroz, etc.) são comparáveis com cargas comerciais tais como o carbonato de cálcio, negros de fumo, sílica precipitada ou talco (CHAUDHARY; JOLLANDS; CSER, 2002).

Os argilominerais são materiais naturais com características peculiares (alta energia superficial, elevada área superficial, alto fator de forma, capacidade de troca catiônica, etc.) que os torna particularmente atrativos para aplicações como cargas em borrachas e plásticos. Adicionalmente os argilominerais são amigáveis ao meio ambiente, disponíveis em grandes quantidades com um custo relativamente baixo e de fácil manuseio. 
A vermiculita é um argilomineral derivado de alteração de micas, que possui a peculiaridade de expandir quando submetida a altas temperaturas, e é dessa característica que decorre seu valor industrial. A vermiculita é usada principalmente na forma expandida em aplicações de isolamento térmico, acústico, barreira contrafogo, agregados leves, condicionador de solos, etc. O comércio de vermiculita no mundo atinge um valor da ordem de 200 milhões dólares ao ano, com uma crescente demanda de aplicativos em países desenvolvidos porém com utilização ainda considerada sofisticada no Brasil, sendo restrita a nichos alternativos-modernos (REIS, 2001).

O Brasil produz perto de $5 \%$ da produção mundial de vermiculita. Esta produção, entretanto, não reflete o real potencial do país, que tem excelentes reservas deste produto. Vários trabalhos tem sido realizados ao longo dos anos, objetivando o desenvolvimento de processos de expansão e hidrofobização da vermiculita, bem como a viabilidade econômica do seu uso industrial (CHUI, 2005; MARTINS, 1991; PINTO, 1994; SANTOS et al., 2002; VIEIRA, 2004). Os resultados destes estudos apontam a vermiculita como um mineral de grande importância econômica, devido à gama de utilizações que pode ser-lhe dada (FRANÇA; LUZ, 2002).

O polipropileno (PP) é um polímero versátil que tem uma ampla variedade de aplicações, é barato, pode ser reprocessado várias vezes sem perda significativa de propriedades, e pode ser facilmente modificado para atingir requisitos específicos. O PP é principalmente utilizado no sector voltado a filmes para embalagens e alimentos, seguido da utilização em componentes técnicos, que incluem o uso do polipropileno em aplicações especificas no sector eletroeletrônico e automobilístico, o PP é bastante usado na produção de peças integrais de plástico para veículos, como os pára-choques e painéis internos, mas também nos corpos de aparelhos eletroeletrônicos (CALLEGARI, 2000).

De todos os termoplásticos, o crescimento do PP sobre os seus 40 anos de existência, foi o mais vigoroso na história dos plásticos. Apenas nos últimos dez anos, o PP teve o mais rápido crescimento entre os plásticos mais importantes, ao redor de $7 \%$ por ano, penetrado em novas áreas anteriormente cobertas por plásticos de engenharia como o acrilonitrila-butadieno-estireno (ABS) ou poliamidas (PA) (PEIJS, 2003). Devido à sua natureza semicristalina o PP apresenta problemas de deformabilidade durante o resfriamento de peças moldadas por injeção. Na correção deste fenômeno utiliza-se cargas minerais, entre elas o carbonato de cálcio, negros de fumo e principalmente o talco. 
A vermiculita é um argilomineral com estrutura cristalina similar à montmorilonita, com a diferença das vermiculitas terem a carga eletrostática das camadas maior devido ao alto grau de substituições na sua estrutura, isto confere-lhes maior estabilidade térmica porém dificulta a dispersão das suas partículas, no entanto, este mineral tem o potencial de gerar partículas com alto fator de forma, se for tratado adequadamente. Recentemente, vários trabalhos tem se focado na modificação das propriedades da vermiculita através de diversos tratamentos químicos e físicos, visando melhorar sua afinidade com substancias orgânicas, aumentar o inchamento e a dispersão dos agregados de vermiculita com o intuito de desenvolver aplicações como cargas em compósitos poliméricos.

Baseados nos resultados do trabalho de Vieira-Coelho (1986) relacionado ao estudo de inchamento de vermiculitas tratadas com soluções de vários cloretos inorgânicos, no qual foram reportados altos índices de inchamento em água e quedas significativas nas capacidades de troca catiônica (CTC), no presente trabalho estudose o efeito do tratamento químico com soluções aquosas de cloreto de lítio, cloreto de sódio e ácido clorídrico sobre a CTC, o inchamento e a distribuição granulométrica das partículas de uma vermiculita originária do estado do Piauí, visando atingir condições adequadas para incorporar as partículas de vermiculita a uma matriz de PP. 


\section{$1.1 \quad$ Objetivos}

- Estudar a influência dos tratamentos químicos adotados nas propriedades físicas e químicas da vermiculita (inchamento em água, capacidade de troca catiônica e distribuição granulométrica das partículas).

- Realizar comparativos entre os tratamentos estudados objetivando identificar o tratamento que gere condições adequadas para a incorporação de vermiculita em polipropileno.

- Fabricar compósitos de polipropileno/vermiculita empregando vermiculita tratada e sem tratamento utilizando técnicas de processamento em estado fundido.

- Avaliar a influência da adição de vermiculita tratada e sem tratamento no desempenho dos compósitos polipropileno/vermiculita. 


\section{REVISÃO DE LITERATURA}

Neste capitulo será apresentada uma breve abordagem sobre conceitos e dados relevantes relacionados aos materiais envolvidos neste trabalho. Nos primeiros ítens serão descritos aspectos gerais da vermiculita, inchamento de argilominerais, polipropileno e materiais compósitos, já no último ítem é apresentado o estado da arte dos trabalhos relacionados com a modificação das propriedades físicas e químicas da vermiculita bem como seu emprego em compósitos poliméricos.

\section{$2.1 \quad$ Vermiculita}

A vermiculita é um aluminosilicato hidratado de magnésio, ferro e alumínio com aparência micácea, formato lamelar e clivagem basal. O termo vermiculita é utilizado também para designar comercialmente um grupo de minerais micáceos constituído por cerca de dezenove variedades de silicatos hidratados de magnésio e alumínio, com ferro e outros elementos (UGARTE; SAMPAIO; FRANÇA, 2005). O nome vermiculita é derivado do latim vermiculari que significa "semelhante a verme" e se deve ao fato de que esse material se expande sob aquecimento, processo durante o qual suas partículas movimentam-se de forma semelhante à dos vermes. O termo vermiculita foi utilizado pela primeira vez por Tomas H.Webb, em 1824, num deposito próximo de Worchester, Massachusetts, EUA.

A vermiculita é um membro importante do grupo dos argilominerais trifórmicos, grupo do qual fazem parte também as esmectitas, as micas e o talco. A célula unitária da vermiculita está formada por um empilhamento 2:1, isto é, duas folhas de tetraedros de silício tetracoordenado e uma folha de octaedros de alumínio hexacoordenado entre elas. Os grupos tetraédricos e octaédricos estão construídos por íons oxigênio e íons hidroxila, ao redor de pequenos cátions, principalmente $\mathrm{Si}^{4+}$ e $\mathrm{Al}^{3+}$ nos grupos tetraédricos, e $\mathrm{Al}^{3+}$ ou $\mathrm{Mg}^{2+}$ nos grupos octaédricos (SOUZASANTOS, 1975a). 
Segundo o tipo de cátion presente na folha octaédrica as vermiculitas podem ser de dois tipos, trioctaédricas quando o cátion predominante é $\mathrm{Mg}^{2+}$ e todas as posições octaédricas estão preenchidas, ou dioctaédricas quando o cátion predominante é $\mathrm{Al}^{3+}$ e duas de três posições octaédricas são ocupadas. Vermiculitas trioctaédricas são encontradas na forma de grandes placas e são conhecidas como macrovermiculitas, por outro lado, as dioctaédricas ou microvermiculitas são encontradas em pequenas dimensões na ordem de micrômetros de diâmetro em argilas e solos. É importante mencionar que apenas as macrovermiculitas apresentam aplicações industriais.

A representação da célula unitária de uma vermiculita trioctaédrica pode ser expressa pela formula:

$$
1,4 \mathrm{M}^{+}(\mathrm{Mg}, \mathrm{Al}, \mathrm{Fe} \text { etc })_{6}\left[(\mathrm{Si}, \mathrm{Al})_{8} \mathrm{O}_{20}\right][\mathrm{OH}]_{4} \quad \text { a }
$$

As três posições octaédricas não costumam estar totalmente preenchidas, e também o magnésio octaédrico pode estar parcialmente substituído por $\mathrm{Fe}^{3+}, \mathrm{Fe}^{2+} \mathrm{e}$ $\mathrm{Al}^{3+}$, a vermiculita apresenta um excesso de carga negativa vinda do grupo $\mathrm{AlO}_{4}^{-}$, devido as substituições de $\mathrm{Si}^{4+}$ por $\mathrm{Al}^{3+}$ na folha tetraédrica segundo Walker (1961) numa relação $\mathrm{Al} / \mathrm{Si}$ de 1:2 e 1:3. Os cátions interlamelares neutralizantes estão rodeados de certa quantidade de moléculas de água, que variam dependo do estado de hidratação, segundo Grim (1968) um cátion de uma vermiculita completamente hidratada pode estar rodeado de até 16 moléculas de água, os cátions que ocorrem na natureza são predominantemente $\mathrm{Mg}^{2+}$, mas $\mathrm{Ca}^{2+}, \mathrm{Na}^{+}, \mathrm{Cu}^{2+} \mathrm{e}_{3} \mathrm{O}^{+}$também podem ocorrer (SOUZA-SANTOS, 1975a). Na Figura 2.1 mostra se um esquema da estrutura cristalina das vermiculitas.

A presença de moléculas de água localizadas no espaço interlamelar da estrutura da vermiculita conferem a propriedade da piroexpansão, quando aquecida a uma temperatura acima dos $250^{\circ} \mathrm{C}$ a vermiculita se expande abruptamente na direção normal à superfície das placas, isto devido à liberação rápida das moléculas de água na forma de vapor, como conseqüência à piroexpansão o macrocristal de vermiculita aumenta seu volume, diminui sua densidade, aumenta a sua área superficial e diminui sua capacidade de troca de cátions significativamente (SOUZA-SANTOS, 1975b).

\footnotetext{
${ }^{a} \mathrm{M}^{+}$refere se ao cátion monovalente que fica entre as camadas basais para neutralizar o desbalanceamento de cargas na estrutura, o numero 1,4 indica a média da carga da camada em equivalentes por formula unitária.
} 


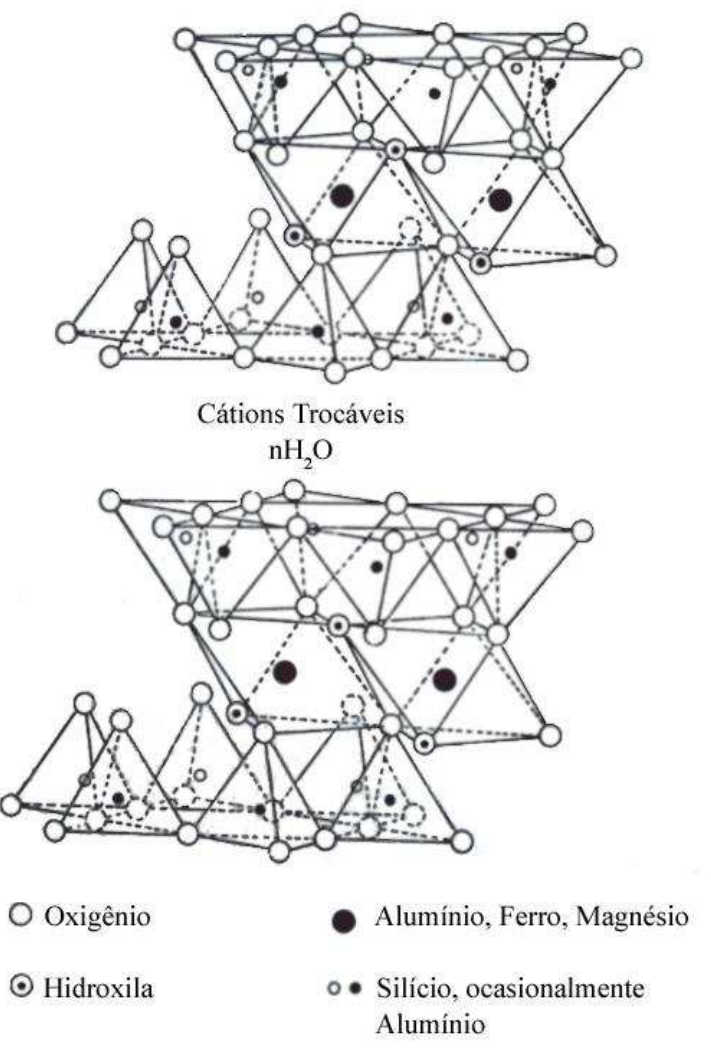

Figura 2.1: Esquema da estrutura cristalina de uma vermiculita (GRIM, 1968) adaptado por Vieira-Coelho (1986).

\subsubsection{Capacidade de troca de cátions}

A capacidade de trocar e reter íons na superfície e no espaço interlamelar existente entre as camadas da estrutura cristalina dos argilominerais é uma propriedade de enorme importância em todas as áreas onde os argilominerais são utilizados, devido a que os íons trocáveis influem fortemente nas propriedades físicoquímicas e tecnológicas dos argilominerais. Como resultado os fenômenos de troca e retenção de íons são discutidos amplamente em vários trabalhos (CHUI, 1998; SANTOS, 2006; SHINZATO, 1995; VIEIRA-COELHO, 1986).

A capacidade de troca de cátions (CTC) de um argilomineral pode ser definida como a quantidade de cátions disponíveis para serem trocados num determinado $\mathrm{pH}$ (BERGAYA; THENG; LAGALY, 2006). A CTC esta relacionada com a quantidade de cargas negativas presentes na estrutura cristalina, ocasionadas pelas substituições isomórficas nas folhas de octaedros e de tetraedros, e à carga gerada pelas ligações quebradas nas arestas das folhas, que dependendo do $\mathrm{pH}$ podem ser completadas com $\mathrm{H}_{3} \mathrm{O}^{+}, \mathrm{H}_{2} \mathrm{O}$ ou $\mathrm{OH}^{-}$. Nas vermiculitas, $80 \%$ da capacidade de troca de cátions se deve à substituição na estrutura cristalina nas camadas 2:1 e o restante às superfícies laterais da partícula (SOUZA-SANTOS, 1975a). 
Tabela 2.1: Capacidade de troca de cátions dos argilominerais (BERGAYA;

LAGALY; M., 2006).

\begin{tabular}{ll}
\hline & meq/100g \\
\hline Caulinita & $3-15$ \\
Haloisita. $2 \mathrm{H}_{2} \mathrm{O}$ & $5-10$ \\
Haloisita. $4 \mathrm{H}_{2} \mathrm{O}$ & $40-50$ \\
Montmorilonita & $70-120$ \\
Vermiculita & $130-210$ \\
Ilita & $10-40$ \\
Micas (biotita, moscovita) & acima de 5 \\
Clorita & $10-40$ \\
Sepiolita, Paligorsquita & $20-30$ \\
\hline
\end{tabular}

A CTC é expressa geralmente em miliequivalentes (meq) por $100 \mathrm{~g}$ de amostra seca, a CTC da vermiculita é relativamente alta e é um dos argilominerais que apresenta maior valor de CTC, sendo apresentados em literatura valores de até 210 meq/100g. Na Tabela 2.1 se mostra a faixa usual de troca de cátions de vários argilominerais, é usual que os valores de CTC sejam apresentados em amplas faixas devido a que podem ser influenciados por vários fatores, tais como, a natureza dos cátions permutáveis, o tamanho da partícula, temperatura de reação e de até mesmo das condições do método utilizado, como resultado é difícil determinar o CTC com precisão. A CTC dos argilominerais pode ser determinada por vários métodos sendo o mais utilizado o método que envolve o deslocamento dos cátions do espaço lamelar por um cátion índice de uma solução de volume e concentração conhecida, a determinação do cátion índice é feita por técnicas estándar como absorção, espectrofotometria ou titulação.

\subsubsection{Produção mundial e no Brasil}

\subsubsection{Produção mundial}

O comércio de vermiculita no mundo atinge um valor da ordem de 200 milhões de dólares ao ano, com uma crescente demanda de aplicativos em países desenvolvidos porem com utilização ainda considerada sofisticada no Brasil, a produção mundial no 2007 foi estimada em 520 mil toneladas fornecida em grande escala pela África do Sul com aproximadamente $39 \%$ da produção mundial de vermiculita, a China e os Estados Unidos ocupam o segundo e terceiro lugar com $21 \%$ e $19 \%$ respectivamente. O Brasil e a Rússia se encontram juntos no quarto lugar com $5 \%$ da produção mundial. Outros países produtores são Argentina, Egito, Índia, Japão, e Quênia. 
Tabela 2.2: Principais produtores de vermiculita no mundo (POTTER, 2008).

\begin{tabular}{lccc}
\hline Pais & \multicolumn{2}{c}{ Produção (t/ano) } & Porcentagem \\
& 2006 & 2007 & $\%$ \\
\hline Estados Unidos & 100 & 100 & 19 \\
Brasil & 25 & 25 & 5 \\
China & 110 & 110 & 21 \\
Rússia & 25 & 25 & 5 \\
África do sul & 198 & 200 & 39 \\
Zimbabwe & 20 & 13 & 2 \\
Outros Países & 42 & 47 & 9 \\
Total Mundial & 520 & 520 & 100 \\
\hline
\end{tabular}

Na ultima década a África do Sul e os Estados Unidos, passaram a dividir o mercado com novos fornecedores como a China, Zimbabwe, Austrália e Índia. A China em particular, tem apresentado um desenvolvimento comercial crescente se estabelecendo como um grande competidor no mercado mundial de vermiculita (UGARTE; SAMPAIO; FRANÇA, 2005).

\subsubsection{Produção brasileira}

O Brasil, apesar da produção modesta de 25.000t/ano e mercado de aplicativos incipiente, aparece como quarto maior produtor junto com a Rússia com 5\% da produção. No Brasil há depósitos e jazidas de vermiculita nos estados de Goiás, Paraíba, Bahia, Piauí e São Paulo. Segundo Reis (2001) as principais áreas produtivas estão localizadas no município de Paulistana no Piauí e na região oeste de Goiânia em Goiás. Os minérios brasileiros não contêm asbestos, o que confere aos concentrados de vermiculita maior valor agregado, além de favorecer o melhor aproveitamento econômico do mineral.

Tabela 2.3: Reservas minerais no Brasil (CAVALCANTI, 2005).

\begin{tabular}{lcc}
\hline Unidades da Federação & \multicolumn{2}{c}{ Reserva lavrável } \\
& minério (t) & teor (\%verm.) \\
\hline Bahia & 3.260 .074 & 55,00 \\
Goiás & 9.758 .327 & 8,91 \\
Paraíba & 2.572 .251 & 32,44 \\
Piauí & 87.128 & 100,00 \\
São Paulo & 45.488 .934 & 6,03 \\
\hline
\end{tabular}


Tabela 2.4: Principais empresas produtoras no Brasil (CAVALCANTI, 2006).

\begin{tabular}{lcc}
\hline Empresa & Unidade de Federação & $\begin{array}{c}\text { Participação } \\
(\%)\end{array}$ \\
\hline Mineração Phoenix Ltda. & BA & 0,81 \\
Brasil Minérios Ltda. & GO & 61,34 \\
Mineração Pedra Lavrada Ltda. & PB & 4,33 \\
Eucatex Mineral Ltda. & PI & 33,51 \\
\hline
\end{tabular}

A vermiculita, embora seja comercializada na sua forma não expandida, é utilizada em maior parte na forma expandida, o preço da vermiculita não expandida pode começar com US\$120/t FOB enquanto a expandida sobe para até US\$490/t (CAVALCANTI, 2007). A produção brasileira esta concentrada em quatro produtores como mostra a Tabela 2.4 .

\subsubsection{Usos e funções}

A vermiculita apresenta características peculiares, é um material não abrasivo, inodoro, de pH essencialmente neutro, inerte, não se decompõe e possui propriedades isolantes térmicas devido a sua alta temperatura de sinterização. uma vez expandida a vermiculita apresenta baixa densidade, características de isolante acústico, alta absorção de líquidos e elevada área superficial; tais propriedades permitem que seja utilizada em varias aplicações e principalmente na forma expandida.

A aplicação da vermiculita para um uso específico depende da sua granulometria, assim, o material com granulometria mais fina é aplicada na produção de manufaturados para a construção civil, além de ser utilizado como veículo na produção de fertilizantes e de alimentação para animais. As de granulometria mais grossa são utilizadas para fins de horticultura, cultivo e germinação de sementes, dentre outros. A seguir são descritos alguns exemplos de usos de vermiculita no mercado mundial.

\subsubsection{Construção civil}

- Isolante térmico e acústico em paredes, na forma de massa para revestimento, solto pode ser aplicado no isolamento termoacústico de forros, assoalhos e paredes.

- Miolo de divisórias e portas corta-fogo.

- Agregado leve para concreto. 
- Carga em tintas e massas anti-fogo para paredes, teto e portais.

- Massa em blocos de concreto e tijolos leves para construção.

- Argamassa de proteção em piscinas de vinil.

\subsubsection{Indústria}

- Isolante termo acústico para construção naval.

- Revestimento para tubulações.

- Revestimento de moldes para fundição de ferro e alumínio.

- Moldes de proteção de estruturas metálicas submetidas a temperaturas elevadas.

- Elemento filtrante.

- Blocos e cerâmicas refratárias.

- Absorção de óleos, pesticidas e metais pesados.

- Componente de aumento de viscosidade de óleos lubrificantes.

\subsubsection{Agricultura e horticultura}

- Fonte de nutrientes $\mathrm{Ca}, \mathrm{K}, \mathrm{Mg}$ no período de estiagem.

- Retentores de água em jardinagem e agricultura.

- Germinação de sementes.

- Condicionador de solos ácidos e argilosos.

- Veículo para inseticidas, herbicidas, fungicidas e fumigantes.

\subsubsection{Outras aplicações}

- Fabricação de pneus e pastilhas de freio.

- Pastas e lubrificantes inertes não graxosos.

- Embalagens a prova de choque e fogo.

- Incubação de ovos de répteis. 
- Confecção de pedras artificiais.

- Casco de barcos e canoas.

\section{$2.2 \quad$ Inchamento de argilominerais}

O termo inchamento é utilizado para descrever o fenômeno do aumento do volume externo do torrão de argila ou agregado de partículas de argilominerais (VIEIRACOELHO, 1986). O fenômeno de inchamento está associado principalmente com a hidratação dos cátions interlamelares presentes nas argilas e a forma como as moléculas de água são dispostas ao redor dos cátions, portanto o inchamento em argilominerais é principalmente controlado pelo tipo do cátion e conseqüentemente pela energia de hidratação, por outro lado, a influência exata da carga tedraedral e a densidade de carga ainda não tem sido esclarecidas totalmente (MICHOT et al., 2002).

Em função ao espaço interlamelar entre nas camadas 2:1, Norrish (1954) propôs uma série de passos o etapas seqüenciais para descrever o inchamento de esmectitas em água, a primeira etapa é denominada inchamento cristalino e envolve a hidratação dos cátions presentes no espaço interlamelar do argilomineral, a segunda é chamada de inchamento osmótico e envolve a formação de uma dupla camada difusa ao redor dos agregados do argilomineral, já a ultima etapa descreve a dispersão dos aglomerados e a formação de uma rede aleatória das partículas.

Recentemente Laird (2006) estudou a influência da carga da camada no inchamento de esmectitas no sistema aquoso, e adiciona três processos de inchamento às etapas propostas por Norrish (1954), não obstante os processos descritos por Laird não tem uma ordem seqüencial, podendo acontecer simultaneamente durante o inchamento osmótico também conhecido como inchamento de dupla camada.

As etapas descritas por Norrish (1954) e Laird (2006) são perfeitamente aceitáveis para a maioria dos argilominerais 2:1, devido a vários aspectos comuns quando interagem com água, todos eles possuem cátions interlamelares devido as substituições, e apresentam o espaçamento interlamelar onde é formada a estrutura parcialmente ordenada de moléculas de água ao redor dos cátions, não obstante a intensidade do inchamento difere de mineral para mineral. 


\subsubsection{Inchamento cristalino}

Também chamado de inchamento microscópico por causa do incremento no espaço interlamelar estar restrito de 10 a 22 angstroms, ocorre entre as camadas individuais dentro do agregado de partículas do argilomineral, resulta da absorção de água devido à hidratação parcial dos cátions e acontece numa série discreta de passos para a formação de 1, 2, 3 e 4 camadas de água. É controlado pelo balanço entre as fortes forças eletrostáticas de atração e as forças repulsivas de hidratação.

\subsubsection{Inchamento osmótico}

A passagem do inchamento cristalino para o inchamento de dupla camada acontece quando energia de hidratação do cátion supera a barreira de potencial devida às forças eletrostáticas de atração, aumentando continuamente a quantidade de água absorvida, alcançando espaçamentos interlamelares na ordem de 30 a valores acima de 100 angstroms.

O inchamento de dupla camada, em contraste com o inchamento cristalino acontece entre agregados de partículas, está etapa esta associada à formação de uma dupla camada difusa entre os agregados de partículas. Uma pequena porção da carga total é expressada na superfície externa da partícula, esta carga negativa da superfície externa é conhecida como a camada de Stern e forma a metade da dupla camada difusa. Na solução adjacente à camada de Stern forma-se uma rede de cargas positivas, formando a outra metade da dupla camada difusa, nesta camada os íons positivos são ainda atraídos pela carga negativa da partícula, mas estes são rejeitados pela camada de Stern assim como pelos outros íons positivos que intentam aproximar-se. Este equilíbrio dinâmico resulta na formação da dupla camada difusa que envolve as partículas de argilominerais.

\subsubsection{Formação e separação de agregados}

As moléculas de água estão em constante colisão com as partículas dentro da suspensão aquosa, cada colisão transfere energia cinética das moléculas de água para a partícula e viceversa, quando dois partículas se aproximam com suficiente energia cinética para superar a força de repulsão da dupla camada uma porção difusa de suas duplas camadas se chega a unir, quando isto acontece, ânions, cátions em excesso e água são expelidos da região de contato entre as duas superfícies, como resultado as duas partículas ficam juntas formando um agregado maior, de maneira 
semelhante forças aerodinâmicas causadas por agitação, excitação, sonificação, impacto, etc. podem cortar uma partícula grande para formar dois ou mais agregados ou camadas individuais.

\subsubsection{Desaglomeração preferencial devido ao tipo de cátion}

Este fenômeno ocorre quando mais de um tipo de cátion trocável está presente no empilhamento de camadas de uma partícula de um argilomineral, se o sistema for agitado nesta condição existe a possibilidade da desaglomeração da partícula ocorrer em certos espaços interlamelares, predominantemente nos espaços interlamelares dominados pelo cátion ligado mais fracamente à partícula, como é mostrado na Figura 2.2.

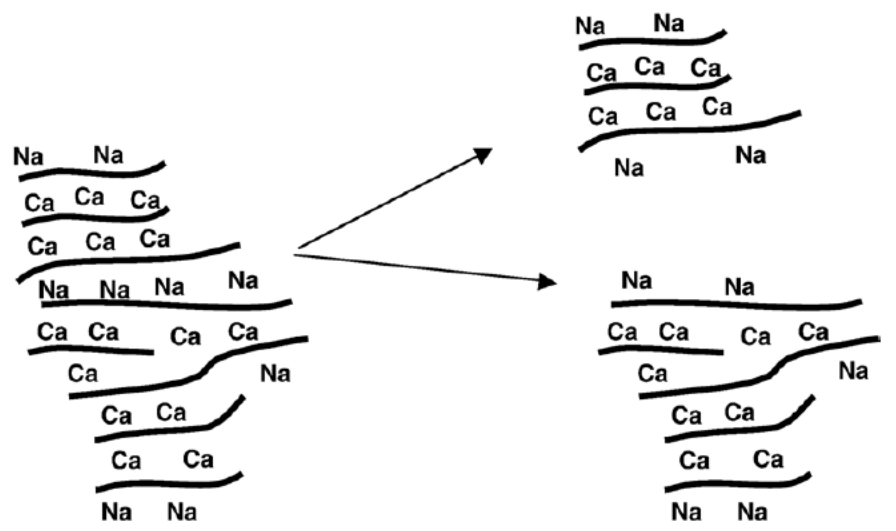

Figura 2.2: Esquema da desaglomeração preferencial devido ao tipo de cátion (LAIRD, 2006).

\subsubsection{Inchamento de co-volume}

O inchamento de co-volume está associado ao movimento rotacional das partículas na suspensão, as partículas estão em constante movimento devido as constantes colisões das moléculas de água com as partículas na suspensão aquosa, no entanto, devido ao fato das partículas serem anisométricas apresentam também um movimento rotacional, sendo o volume rotacional efetivo determinado pela dimensão da partícula e da dupla camada associada a esta, portanto, quando dois partículas se aproximam a primeira interação se realizara na porção difusa da dupla camada o que irá resultar em uma força repulsiva antes de que as partículas se toquem. 
O inchamento de co-volume está relacionado diretamente com o incremento na entropia devida ao incremento da liberdade rotacional das partículas na suspensão, por exemplo se mais água é cuidadosamente adicionada na suspensão, as partículas irão se expandir no novo volume de água.

\subsubsection{Inchamento browniano}

No inchamento browniano as camadas individuais estão amplamente dispersas na suspensão aquosa, é um processo impulsionado pela entropia resultado da movimentação termal aleatória das partículas na suspensão aquosa, e não existe interação entre as camadas vizinhas.

Laird (2006) relacionou as etapas de inchamento com a CTC, determinando que o incremento na carga da camada resulta na diminuição no inchamento cristalino e no incremento do tamanho e estabilidade dos agregados. Além disso, a carga da camada tem pouca influência ou pode influir indiretamente no inchamento de dupla camada, de co-volume e browniano. No entanto, influi diretamente no tamanho e estabilidade dos agregados dos argilominerais, afetando fortemente o processo de formação e separação de agregados, bem como na seletividade dos cátions quando acorre a desaglomeração preferencial devido ao tipo de cátion.

\subsection{Materiais compósitos}

O progresso tecnológico tem como componente importante o desenvolvimento de novos materiais que possam satisfazer requerimentos específicos em termos de desempenho estrutural e funcional, assim como a otimização do seus processos de fabricação, nesse sentido muitas tecnologias não teriam sido possíveis sem o recurso dos novos materiais. Um claro exemplo deste processo de desenvolvimento são os materiais compósitos (VASILIEV; MOROZOV, 2001).

Os materiais compósitos são materiais multifásicos projetados de modo a conjugar características desejáveis de dois ou mais constituintes, usualmente, estão formados por uma fase contínua que envolve a outra fase dispersa, a fase continua é denominada matriz e pode ser polimérica, metálica ou cerâmica, da mesma forma a fase dispersa pode apresentar diferentes formatos tais como partículas, fibras, bastonetes, lâminas ou plaquetas (PADILHA, 1997). 
As propriedades dos compósitos são uma função das propriedades das fases constituintes, das suas quantidades relativas e da geometria da fase dispersa, ou seja, a forma das partículas e o tamanho, distribuição e orientação das partículas (CALLISTER, 1991).

\subsubsection{Compósitos de matriz polimérica}

Os compósitos de matriz polimérica constituem o material compósito que melhor tem se estabelecido na atualidade. Desde seu surgimento a meados do século XX tem se desenvolvido rapidamente trazendo mudanças em diferentes áreas, sendo utilizado desde aplicações em mercados avançados (militar, espacial, esportivo e aeronáutico), até as aplicações mais simples (decoração, embalagens, entre outras). Além disso, substitui de forma crescente materiais tradicionais em aplicações de engenharia como a construção civil, automobilística e nos setores de elétricos e eletrônicos (GIORDANO; IANNACE; NICOLAIS, 2001; SONMEZ; AKBULUT, 2007).

Os compósitos poliméricos podem ser termoplásticos ou termorrígidos, a principal diferença entre estes dos materiais está no comportamento característico quando aquecidos, isto é, os termoplásticos tornam se fluidos sob ação da temperatura e solidificam quando resfriados, este processo pode ser repetido varias vezes, por outro lado os termorrígidos permanecem duros e não amolecem quando aquecidos (CALLISTER, 1991). A escolha da matriz polimérica dependerá das propriedades físicas, mecânicas e térmicas exigidas para uma determinada aplicação, como também do processo de fabricação escolhido e do custo associado.

Mais de $70 \%$ das matrizes empregadas nos materiais compósitos de matriz polimérica são termorrígidas, isto devido a que geralmente os termorrígidos são mais duros e resistentes que os termoplásticos e possuem melhor estabilidade dimensional, como resultado são os mais utilizados em aplicações estruturais. As resinas termorrígidas mais utilizadas são as poliésteres, poliuretanos, vinilésteres e as resinas fenólicas (MATTHEWS; RAWLINGS, 1999).

Por outro lado os compósitos de matriz termoplástica, oferecem outras características atrativas sobre os compósitos termorrígidos como por exemplo, boa resistência ao impacto, ilimitado prazo de validade das matérias primas, alta qualidade superficial, permitem a fabricação de peças com altas taxas de produção, possibilidade de reprocessar peças defeituosas e a possibilidade de reciclagem das matérias primas (WEISS, 1991; MATTHEWS; RAWLINGS, 1999; BRONDSTED; LILHOLT; LYSTRUP, 2005). 
Apesar do fato dos compósitos de matriz termoplástica serem menos empregados como matrizes, apresentam uma crescente expansão em relação aos compósitos termorrígidos isto devido as tendências atuais, materiais com potencial para serem reciclados apresentam maior demanda nos mercados de consumo, além disso, o desenvolvimento de polímeros de alta performance com alta massa molar e alta cristalinidade que toleram maiores temperaturas e oferecem melhores propriedades mecânicas, tem tornado os termoplásticos mais competitivos e tem gerado uma grande expectativa nos plásticos de engenharia tais como as poliamidas, polisulfonas, poliéter sulfona, poliéter éter sulfona, dentre outros materiais. Na ultima década países de Europa assim como os Estados Unidos e Japão tem reconhecido a necessidade de expandir os campos de aplicação dos compósitos termoplásticos e melhorar o entendimento dos processos de fabricação (GIORDANO; IANNACE; NICOLAIS, 2001).

\subsection{Polipropileno}

O polipropileno é uma poliolefina obtida através da polimerização do propeno, por médio de catalisadores Ziegler-Natta. Este termoplástico se caracteriza por ser bastante versátil, com um grande numero de aplicações, entre as quais se incluem as que utilizam os copolímeros e os compósitos. O polipropileno possui características que lhe conferem certas vantagens sobre outros termoplásticos, tais como boa barreira aos gases, ser inquebrável, transparente, brilhante, rígido e resistente a mudanças de temperatura (CALLEGARI, 2000).

Até meados dos anos 50 as poliolefinas de importância comercial eram apenas o polietileno, poliisobutadieno e o copolímero isobutadieno-isopreno, as primeiras tentativas em polimerizar outras poliolefinas tiveram como resultado a preparação de materiais de baixo peso molecular e sem valor comercial aparente (BRYDSON, 1995).

A viabilidade comercial do PP foi possível apenas a partir de 1955, com o trabalhos de Natta na Itália, utilizado o sistema catalisador estereoespecifico de Ziegler, o desenvolvimento dos catalisadores Ziegler-Natta permitiram o controle da estereoquímica durante a polimerização do $\mathrm{PP}$ e outras poliolefinas, levando à obtenção de materiais com estruturas regulares isotática e sindiotática, com propriedades de interesse comercial (SARANTÓPOULOS et al., 2002). 
Após a descoberta do catalisador Ziegler-Natta a exploração comercial do PP foi muito rápida. O PP começo a ser comercializado no começo dos anos 1957. Na atualidade é uma das poliolefinas mais utilizadas no mundo, com uma produção mundial de aproximadamente 46,982 milhões de toneladas em 2007 (RESEARCH; MARKETS, 2008).

O PP um dos termoplásticos mais consumidos no mundo todo, o crescimento do PP sobre os seus 40 anos de existência, foi o mais vigoroso na história dos plásticos. Apenas nos últimos dez anos, o PP teve o crescimento mais alto de entre os principais plásticos, ao redor de $7 \%$ por ano, penetrando em novas áreas de aplicação anteriormente cobertas por plásticos de engenharia como o ABS ou poliamidas (PEIJS, 2003). Acredita-se que o seu potencial de crescimento deve-se sobretudo à sua versatilidade para diversas aplicações (CALLEGARI, 2000).

O PP pode ser sintetizado em três formas isotática, sindiotática e atática, o catalisador Ziegler-Natta é utilizado para produzir PP estereoregular (isotático e sindiotático), porém este não é perfeitamente estereoregular, sendo que o grau de isotaticidade varia de 88 a $97 \%$. Os PP isotático e sindiotático formam arranjos cristalinos regulares, obtendo polímeros mais rígidos, ambos são cristalinos, no entanto, o PP sindiotático tem uma temperatura de fusão menor que o PP isotático (HARPER, 2002). Como regra geral nos polímeros comerciais, quanto maior o teor de isotático, maior a cristalinidade, maior o ponto de fusão cristalina, maiores a resistência à tração e a dureza. As demais propriedade não se alteram (SARANTÓPOULOS et al., 2002).

O PP atático possui baixos valores de cristalinidade de entre 5 a $10 \%$ devido a sua estrutura irregular, como resultado este material é macio e flexível, sendo empregado na composição de selantes e adesivos (HARPER, 2002).

Em relação aos monômeros utilizados na reação, o PP pode ser classificado em homopolímero, quando só o propileno é utilizado como matéria-prima, e copolímero, quando o polímero contém cerca de $4 \%$ de eteno. O homopolímero apresenta baixa densidade, mas tem resistência ao impacto e rigidez, resistência a altas temperaturas, à umidade, a reagentes químicos, facilidade de transformação e decoração. Já o copolímero é mais resistente ao impacto, especialmente em baixas temperaturas (CALLEGARI, 2000).

O PP homopolímero apresenta densidade específica da ordem de $0,9 \mathrm{~g} / \mathrm{cm}^{3}$, ponto de fusão cristalina em torno de 140 a $150^{\circ} \mathrm{C}$, boa barreira ao vapor de água, média barreira a gases, boa resistência a óleos e gorduras e a produtos químicos, boa 
resistência à abrasão, boa estabilidade térmica e não é suscetível ao fissuramento sob tensão (stress cracking), entretanto, é sensível à degradação oxidativa a altas temperaturas, requerendo antioxidantes para seu processamento. Caso não seja protegido, se degrada pela ação da luz ultra violeta (UV) e por agentes ionizantes. Da mesma maneira, o PP promove a formação de compósitos de baixo peso molecular (SARANTÓPOULOS et al., 2002).

O polipropileno é um polímero versátil tem uma ampla variedade de aplicações; o maior mercado para o polipropileno é o segmento de transformação voltado a filmes para embalagens e alimentos, em seguida, estão os componentes técnicos, que incluem o uso do polipropileno em aplicações específicas no setor automobilístico e eletroeletrônico. O PP é bastante usado na produção de peças integrais de plástico para veículos, como os pára-choques e painéis internos. mas também nos corpos de aparelhos eletroeletrônicos (CALLEGARI, 2000).

Fibras são outra aplicações importante do PP, particularmente em tecido para tapetes, devido a seu baixo custo e resistência (HARPER, 2002). O PP é usado também na composição de selantes e adesivos, porém na sua forma atática e em quantidades menores em comparação com o PP cristalino, considerando que os polímeros comerciais são de 90 a $95 \%$ isotáticos (EBEWELE, 2000).

\subsection{Incorporação de argilominerais como cargas}

O termo carga se refere a aditivos sólidos que são incorporados na matriz plástica, geralmente são materiais inorgânicos e podem ser classificados de acordo a seus efeitos sobre as propriedades mecânicas no compósito. Cargas inertes são adicionados principalmente com o objetivo de reduzir o preço em relação ao polímero puro, enquanto cargas de reforço são adicionadas para melhorar determinadas propriedades mecânicas, tais como, o módulo de elasticidade e a resistência à tração. Apesar de ser denominadas inertes, cargas inertes podem afetar outras propriedades, podem incrementar a densidade do compósito, reduzir a contração, incrementar a dureza, e incrementar a temperatura de deflexão térmica (HDT) (HARPER, 2002).

A aplicação de cargas minerais se desenvolveu, inicialmente, em bases mais empíricas. As indústrias norte-americana e européia, no entanto, logo descobriram que a partir de conhecimentos mais fundamentais e teóricos de mineralogia, dos mecanismos de ação física e mecânica das partículas minerais nos compósitos plásticos, e da natureza das interfaces químicas mineral/polímeros/aditivos, poderia se ampliar as aplicações dos minerais, uma vez otimizadas suas características, 
e criar novos espaços de mercado para aquelas resinas já existentes. Deste modo os primeiros critérios técnicos de formulação de minerais são introduzidos nas indústrias, laboratórios de caracterização mineral são montados e especificações e normas de controle de qualidade são estabelecidas (UGARTE; SAMPAIO; FRANÇA, 2005).

Segundo Sato (1976) para que um material seja utilizado efetivamente em materiais compósitos, numerosos parâmetros, tais como o tamanho da partícula (área superficial, distribuição de granulométrica ,etc.), forma da partícula (cristalinidade, anisotropia ,etc.) e as características superficiais da partícula (estrutura química, fator de aspereza, agregação da partícula, etc.) devem ser considerados.

As partículas de argila geralmente exibem geometria lamelar, com alto fator de forma o que os torna particularmente atrativos para aplicações como cargas em borrachas e plásticos (KOLMER; KUHNEL, 1990). Além disso, são amigáveis ao meio ambiente e disponíveis em grandes quantidades com um custo relativamente baixo.

Uma das mais importantes características das cargas, relacionadas a sua natureza química é o valor de sua energia livre superficial, isto devido a que das condições da interação interfacial entre a matriz e a carga dependem da razão de energia livre na superfície da carga e da matriz. Deste modo os materiais podem se dividir em dois grupos os materiais: de alta (metal, óxidos e outras substâncias inorgânicas) e de baixa (polímeros, substâncias orgânicas) energia superficial (LIPATOV, 1994).

O diâmetro das partículas é um parâmetro que deve ser considerando de fundamental importância, devido a que quanto menor a partícula, maior é a área superficial disponível para a adesão e interação da carga com a matriz, estas interações interfaciais tornam-se mais intensas à medida que o tamanho das fases diminui. Quando o tamanho de uma das fases se aproxima de poucos nanômetros, as propriedades esperadas em escala macroscópicas serão mais fortemente afetadas pelas interações interfaciais (PEREIRA, 2006).

Os argilominerais são substâncias inorgânicas de alta energia superficial, a superfície iônica das argilas apresentam pouca afinidade com os polímeros e em particular com polímeros apolares. A carência de afinidade entre o silicato hidrofílico e o polímero hidrofóbico causam aglomeração do mineral na matriz (OKADA; USUKI, 1995). Tem-se buscado uma solução para este problema através da modificação superficial das argilas com vários agentes, tais como silanos e surfactantes. 
Outros autores tem mostrado os benefícios de incrementar o grau de dispersão dos argilominerais na matriz polimérica (GIANNELIS, 1996; HUSSAIN et al., 2006; KARASEK; SUMITA, 1996; RAY; OKAMOTO, 2003), portanto de especial interesse para a tecnologia alcançar o maior grau possível de delaminação da argila, é dizer, a melhor dispersão e distribuição na matriz polimérica (UTRACKI, 2004).

\subsection{Estado da arte}

Na ultima década, o estudo de cargas alternativas têm despertado o interesse da área científica e em especial do setor industrial. Vários tipos de materiais orgânicos ou inorgânicos, em diferentes formatos e escalas tem sido estudados para aplicações em compósitos poliméricos.

Vários tipos de materiais tem sido estudados para sua aplicação como possíveis cargas em materiais compósitos; materiais em escalas macro, micro ou nano tem sido incorporados em polímeros com diferentes propósitos. Fibras vegetais (SAHEB; JOG, 1999), serragem (DÁNYÁDI et al., 2007), casca de arroz (CHAUDHARY; JOLLANDS; CSER, 2002), etc. tem sido utilizadas com o objetivo de desenvolver novos compósitos utilizando recursos naturais renováveis ou de menor impacto ambiental. Por outro lado, cargas minerais tais como caulim, talco e carbonato de cálcio tem sido utilizados na escala micrométrica para melhorar as propriedades mecânicas, a estabilidade dimensional e obter um produto de menor custo em relação ao polímero puro (HARPER, 2002). Já argilominerais (ALEXANDRE; DUBOIS, 2000; OKADA; USUKI, 2006), nanotubos e nanofibras de carbono (LOZANO; BARRERA, 2001), nanosílica (WU et al., 2005) e nanopartículas metálicas (NAMBOOTHIRY et al., 2007) e de carbeto de silício (MAJEWSKI et al., 2006) são utilizadas em tamanhos nanométricos para obter propriedades mecânicas similares aos compósitos convencionais com menores teores de carga, maior estabilidade térmica, resistência à abrasão ou propriedades ópticas, magnéticas, ou elétricas superiores.

De entre todas as cargas estudadas, os argilominerais tem despertado o maior interesse, devido a suas características particulares, principalmente pela capacidade dos agregados de argilominerais se dispersar em camadas individuais. Outra característica importante é sua superfície química favorável para as reações de troca de cátions com cátions orgânicos ou inorgânicos. Estas duas características dependem do cátion presente na intercamada do argilomineral, e estão relacionadas ao grau de dispersão na matriz (GIANNELIS, 1996; RAY; OKAMOTO, 2003). 
Nos últimos anos, vários autores tem reportado a incorporação de argilominerais em diferentes polímeros, com a tendência de preparar materiais em que a interação entre os componentes ocorre a escala nanométrica (ESTEVES; BARROS-TIMMONS; TRINDADE, 2004). Hectorita, saponita, e montmorilonita são os silicatos em camadas mais amplamente empregados para a preparação de compósitos intercalados ou delaminados (AHMADI; HUANG; LI, 2004).

Outros argilominerais tais como a mica e vermiculita, com estrutura cristalina similar às esmectitas, tem sido pouco estudados para sua aplicação em compostos poliméricos. Muscovita e flogopita pertencem à mesma família, apresentam uma boa cristalinidade e tem uma alta densidade de carga, não obstante, seus cátions interlamelares potássio não são hidratáveis, portanto eles não incham em água e em conseqüência seus cátions não podem ser trocados por outros cátions (OSMAN, 2006).

A vermiculita é um argilomineral com estrutura cristalina similar à montmorilonita, com a diferença da vermiculita ter a carga eletrostática das camadas maior, devido ao alto grau de substituições na sua estrutura (TJONG, 2006), isto lhe confere maior estabilidade térmica que as esmectitas (CABALLERO; PONCELET, 2000). Desafortunadamente a elevada carga da intercamada dificulta a dispersão das suas partículas na matriz polimérica.

A vermiculita é originada por alteração de mica principalmente flogopita e pode ser encontrada em cristais de tamanho considerável, consequentemente, este mineral tem o potencial para produção de camadas de alumino-silicatos com alta razão de aspecto (OSMAN, 2006), se for devidamente tratado e delaminado.

Segundo Liu et al. (2005) poucos estudos tem sido realizados sobre tratamentos para incorporar vermiculita em compósitos poliméricos, embora esta seja um silicato abundante e mais barato que a montmorilonita, hectorita e saponita. A maior parte de estudos realizados tem se focado principalmente na obtenção de compósitos intercalados ou delaminados através de diversos métodos químicos e físicos.

Geralmente, os materiais inorgânicos não têm boa interação com polímeros orgânicos para alcançar uma boa dispersão ou uma adequada aderência, como resultado, tratamentos superficiais são comuns (CHO; PAUL, 2001). Vários métodos tem sido propostos com o objetivo de melhorar a compatibilidade entre vermiculita com polímeros, assim como produzir mudanças na estrutura da vermiculita a fim de promover a delaminação. 
Vermiculitas tem sido tratadas com soluções contendo cátions orgânicos, particularmente íons alquilamônio, este tratamento melhora a afinidade entre o silicato hidrofílico e o polímero hidrofóbico (GIANNELIS, 1996). Além disso, a introdução de moléculas orgânicas no espaço interlamelar produz um aumento no espaço interlamelar do silicato, que é considerado de vital importância para conseguir a sínteses do compósito (OKADA; USUKI, 1995).

Osman (2006) explorou a organofilização de uma vermiculita, monitorando a CTC e a capacidade de cobertura da superfície orgânica de uma vermiculita tratada com sais quaternários de amônio com diferentes tamanhos de cadeia e número de cadeias, os resultados deste trabalho mostraram que as cadeias alquil dos sais estudados formam preferencialmente uma camada dupla dentro do espaço interlamelar, no mesmo trabalho é mostrado também que tratamentos prévios com soluções de $\mathrm{NaCl}$ melhoram a organofilização da vermiculita. Outros autores também tem adotado tratamentos com soluções de $\mathrm{NaCl}$ (JINNAI; SMALLEY; HASHIMOTO, 1996; MARTYNKOVA; VALASKOVA; SUPOVA, 2007; XU et al., 2005) ou de LiCl (BURNSIDE; WANG; GIANNELIS, 1999) como passo prévio à organofilização de vermiculitas.

Martynkova, Valaskova e Supova (2007) realizaram a organofilização de uma vermiculita utilizando brometo de dodeciltrimetilamônio, com o intuito de comparar as mudanças no espaço interlamelar e no tamanho de partícula da organovermiculita antes e depois da incorporação da mesma em uma matriz de acetato de polivinila (PVA), utilizando a técnica de polimerização in situ. Os resultados mostraram que as partículas incorporadas dentro da matriz de PVA apresentaram maior espaçamento interlamelar que as partículas de organovermiculita que não foram incorporadas, além disso as partículas da organovermiculita mostraram maiores tamanhos de partícula após a polimerização in situ.

Xu et al. (2005) estudaram a organofilização de vermiculita empregando brometo de cetiltrimetilamônio para preparar nanocompósitos de carbonato de polipropileno (PPC), a morfologia, o mecanismo de formação e a estabilidade térmica também foram estudados. O estudo mostrou que os agentes de modificação utilizados para a preparação dos nanocompósitos durante o processamento a $170^{\circ} \mathrm{C}$ não sofrem degradação. Por outro lado, Xie et al. (2001) estudaram a estabilidade térmica dos íons alquilamônio na organofilização de montmorilonitas, mostrando que íons alquilamônio podem degradar perto dos $180^{\circ} \mathrm{C}$. 
Ward et al. (1991) pesquisaram o efeito da incorporação de mica, vermiculita, talco, e flocos de alumínio na permeabilidade de filmes de policarbonato (PC), politereftalato de etileno (PET), polietileno (PE) e PP, o estudo mostrou que filmes contendo mica termodelaminada e a vermiculita tratada com uma solução de cloreto de n-butilamônio, apresentaram valores de redução notáveis na permeabilidade em comparação com as outras cargas.

Baseado nos trabalhos de Walker (1960), Garrett e Walker (1962), e SouzaSantos e Riego (1982), relacionados ao estudo de inchamento em água de vermiculitas tratadas com soluções de $\mathrm{LiCl}$, Vieira-Coelho (1986) observou o inchamento em água de vermiculitas tratadas com soluções de vários cloretos inorgânicos em diferentes concentrações, temperaturas e tempos de tratamentos. Os máximos inchamentos foram observados em vermiculitas tratadas com soluções LiCl permitindo a secagem da solução de tratamento, sendo a secagem da solução um fator imprescindível para obter altos inchamentos. No mesmo trabalho VieiraCoelho (1986) sugere que as vermiculitas tratadas, desde que tenham apresentado um inchamento significativo, podem ser facilmente delaminadas por médio de agitação mecânica.

Adicionalmente, as amostras tratadas com soluções de $\mathrm{LiCl}$ permitindo a secagem da solução, que tiveram um inchamento pronunciado, apresentaram uma queda na CTC de entre $15 \%$ e 30\%. Vieira-Coelho (1986) propôs que dito fenômeno ocorre devido à penetração dos cátions $\mathrm{Li}^{+}$dentro da estrutura $2: 1$, através dos espaços hexagonais existentes no folha tetraédrica da vermiculita; este fenômeno seria facilitado pelo processo de secagem da solução de tratamento.

Haro et al. (2003) estudaram o efeito da moagem e o tratamento com vários sais inorgânicos, demonstraram que tanto a moagem como a troca dos cátions naturais da vermiculita por cátions monovalentes $\mathrm{Na}^{+}, \mathrm{Li}^{+}$, e $\mathrm{NH}_{4}^{+}$leva a fortes aumentos na área superficial específica da vermiculita.

Baseados no tratamento proposto por Rittler (1990) para a delaminação de philosilicatos que consiste na exposição dos argilominerais a uma fonte de íons hidrogênio, de preferência ácido fórmico ou ácido clorídrico, vários autores tem descrito a incorporação de vermiculita em vários polímeros tais como PP (TJONG; MENG; HAY, 2002), PE (TJONG; BAO, 2005; TJONG; MENG, 2003), PVA (XU et al., 2003a), Poliamida 6 (PA6) (TJONG; MEnG; XU, 2002b) e blendas PP/PA6 (TJONG; MENG; XU, 2002a), borracha de Etileno-Propileno-Dieno (EPDM) (LIU et al., 2005), utilizando soluções de ácido clorídrico para funcionalizar a superfície da vermiculita 
gerando maior quantidade de grupos $\mathrm{OH}^{-}$na superfície. Anidrido maleico tem sido utilizado nestes trabalhos para melhorar a compatibilidade com a matriz polimérica e aumentar o espaçamento interlamelar da vermiculita.

Adicionalmente, o tratamento ácido gera alterações na estrutura cristalina da vermiculita, que podem ser descritos em 3 etapas: substituição na intercamada de íons $\mathrm{Mg}^{2+}$ por $\mathrm{H}_{3} \mathrm{O}^{+}$, dissolução dos cátions da folha octaédrica e a expulsão dos cátions tetraédricos (SUQUET et al., 1994). Segundo Hart e Brown (2004) a expulsão dos íons metálicos da estrutura da argila, incrementa a área superficial externa da argila introduzindo mesoporosidade permanente. Além disso o tratamento ácido também dissolve algumas impurezas presentes nas argilas tais como a calcita (VALENZUELA-DÍAZ; SOUZA-SANTOS, 2001). No entanto, é importante mencionar que a exposição da vermiculita à solução ácida por longos períodos de tempo leva à destruição da sua estrutura e à formação de um resíduo com elevada área superficial, constituído principalmente por sílica amorfa e óxidos de ferro (MAQUEDA et al., 2009).

$\mathrm{Xu}$ et al. (2003a) estudaram as mudanças no espaçamento interlamelar das vermiculitas, após de serem tratadas por diferentes períodos de exposição a uma solução $2 \mathrm{M}$ de $\mathrm{HCl}$ a temperatura ambiente, demonstrando que tratamentos por tempos maiores que 12 horas resultam na destruição da estrutura cristalina da vermiculita.

Tjong e Bao (2005) estudaram o efeito da incorporação da vermiculita tratada com solução ácida na cristalização de PE, demonstrando que as camadas dispersas de silicatos atuam como agentes de nucleação durante a cristalização das esferulitas, levando a propriedades mecânicas superiores.

Liu, Du e Meng (2006) estudaram o efeito da incorporação de vermiculitas tratadas com $\mathrm{HCl}$, nas propriedades térmicas e elétricas do nanocompósitos vermiculita/polianilina, concluindo que a incorporação de vermiculita melhora a estabilidade térmica, porém reduz a condutividade elétrica do compósito.

O anidrido maleico é um agente compatibilizante frequentemente utilizado nos trabalhos relacionados à síntese de nanocompósitos de polipropileno. Kawasumi et al. (1997) foram os primeiros em processar nanocompósitos de PP/argila organofílica em presença de PP grafitizado com anidrido maleico (PP-g-AM), utilizando técnicas convencionais de processamento. Normalmente estas técnicas envolvem a preparação de um "master batch" feito de argila organofílica intercalada com PP-g-AM, e a diluição deste num PP puro (RUIZ-HITZKY; MEERBEEK, 2006). 
Vários autores tem estudado a influência do peso molecular e a porcentagem de anidrido maleico no PP-g-MA na síntese de nanocompósitos (GARCÍA-LÓPEZ et al., 2003; LONKAR et al., 2009; XU et al., 2003b). Os resultados destes trabalhos apontam ao PP-g-AM como um dos agentes de compatibilização mais adequados para a obtenção de compósitos intercalados ou delaminados. Não obstante, o tipo de argila e organofilização se mostram como fatores mais importantes que a modificação do PP (RUIZ-HITZKY; MEERBEEK, 2006).

A razão das quantidades de PP-g-AM/argila é um parâmetro de vital importância para alcançar ótimas propriedades nos nanocompósitos. Hasegawa et al. (1998) determinaram que razão mais adequada para alcançar ótimas propriedades mecânicas é uma relação de 3/1 de PP-g-AM/argila, porem a porcentagem de anidrido maleico no PP-g-AM não é mencionado neste trabalho.

Por outro lado García-López et al. (2007) realizaram um estudo de otimização da razão de PP-g-AM/argila, demonstrando que razões menores as normalmente usadas (3/1) conduzem á obtenção de ótimas propriedades mecânicas. Além disso demonstraram que o grau de funcionalização do PP-g-AM pode ser baixo, isto porque as propriedades do compósito estão relacionadas com a porcentagem final de anidrido maleico, porcentagens de 0,07 a 0,1\% em peso de anidrido maleico no compósito, foram as mais favoráveis para obter ótimas propriedades mecânicas.

Ristolainen et al. (2005) estudaram o efeito da adição de um PP-g-AM com um grau de funcionalição de $0,5 \%$ em peso de anidrido maleico, na dispersão das partículas de uma montmorilonita organofílica em uma matriz de PP. Dois razões de PP-g-AM/argila foram comparadas $2 / 1$ e $1 / 1$, os resultados indicaram que o maior grau de desaglomeração das partículas foi obtido com razões de 2/1 de anidrido maleico/argila, equivalentes a $0,1 \%$ em peso de anidrido maléico no compósito.

Recentemente, Shao, Wang e Ma (2005) demonstraram que é possível delaminar parcialmente as camadas da argila no estado sólido, utilizando um equipamento de moagem denominado "pan mill", que pode exercer fortes forças de compressão na direção normal e forças de corte nas direções radial e tangencial.

Em outros trabalhos Shao e Wang (2006), Shao et al. (2006) estudaram a morfologia e as propriedades mecânicas e térmicas de nanocompósitos de vermiculita numa matriz de PP sem a utilização de agentes compatibilizantes, preparados a traves do equipamento "pan mill"; descreveram o mecanismo de delaminação em três etapas simultâneas pulverização, deslizamento nas camadas e delaminação. 
Kristkova, Weiss e Filip (2004) estudaram as mudanças estruturais produzidas pela desidratação na vermiculita-Mg incorporada em compósitos de resina fenólicas sem tratamento prévio, isto com o objetivo de estimar a temperatura na superfície do compósito durante processos de fricção, por médio das mudanças no espaçamento interlamelar da vermiculita.

Vaia e Giannelis (1997) estudaram a influência das características dos silicatos e polímeros na formação de compósitos intercalados ou delaminados via processamento no estado fundido. Demonstraram que a intercalação depende criticamente da funcionalização do silicato e das existência de interações polares, que poderiam ser determinados pelas energias superficiais do silicato e o polímero. Polímeros intercalados com maior sucesso exibem caráter polar ou contém grupos ácido ou base.

Fornes et al. (2001) estudaram o efeito do peso molecular na estrutura e nas propriedades dos nanocompósitos PA6/argila. Seus estudos concluíram que compósitos intercalados baseados em poliamidas com altos pesos moleculares tem maior grau de delaminação comparado com um nanocompósito baseado em poliamidas com baixos pesos moleculares.

Técnicas convencionais de processamento como a extrusão podem ajudar a formação de compósitos intercalados e delaminados, contudo existe pouca literatura disponível para a fabricação de nanocompósitos via processamento em estado fundido (TJONG; MENG; HAY, 2002).

Dennis et al. (2001) demonstraram que o grau de delaminação e dispersão de nanocompósitos PA6 e silicatos em camadas processados via processamento em estado fundido é afetado além do tratamento químico, pelo tempo de residência e pelo de grau das forças de corte geradas na extrusora, que são determinadas por sua vez pelo desenho dos parafusos empregados no processamento. Determinaram também que o incremento no tempo de residência na extrusora geralmente melhora a delaminação e dispersão, no entanto, para obter um ótimo grau de mistura são precisas baixas o medianas forcas de corte para melhorar a entrada do polímero no espaço interlamelar da argila. Em função ao tempo de residência e o grau de intensidade de corte, avaliaram 4 extrusoras utilizando vários tipos de parafusos, os estudos concluíram que a melhor dispersão e grau de delaminação são obtidas utilizando medianas forças de corte por longos períodos de residência.

A preparação de compósitos intercalados ou delaminados utilizando as técnicas convencionais de processamento em estado fundido exibem muitas vantagens sobre os outros métodos de síntese. O processamento em estado fundido é específico para 
polímeros e pode levar à síntese de compósitos que não podem ser sintetizados via polimerização in situ ou em solução; além disso, a ausência de um solvente torna a intercalação no estado fundido ambientalmente correta e um método economicamente favorável para as indústrias a partir de uma perspectiva de resíduos (RAY; OKAMOTO, 2003), tornando o processamento em estado fundido atrativo pelas suas potenciais aplicações comerciais. 


\section{MATERIAIS E MÉTODOS}

Neste capitulo serão descritos os materiais e os procedimentos experimentais empregados no decorrer da pesquisa, assim como as técnicas utilizadas para caracterização das amostras deste trabalho.

\subsection{Síntese das atividades}

No diagrama de blocos apresentado na Figura 3.1 ilustra-se de forma resumida a metodologia empregada durante o desenvolvimento deste trabalho. A descrição de cada ítem será abordado conforme a seqüencia apresentada no diagrama.

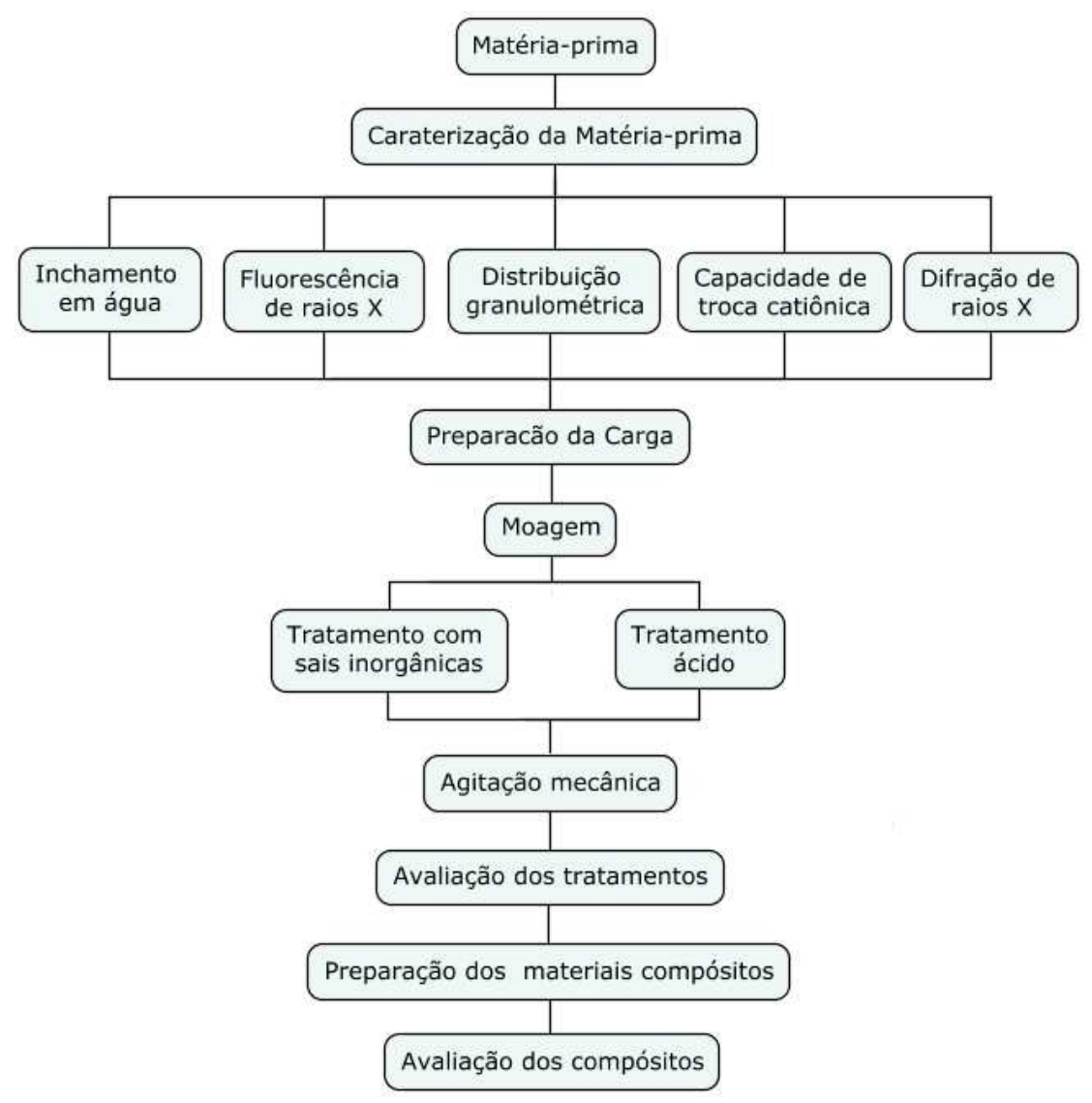

Figura 3.1: Esquema de atividades . 


\subsection{Descrição dos materiais}

A amostra de vermiculita utilizada no presente trabalho foi fornecida pela empresa Eucatex Química e Mineral Ltda. proveniente da jazida de Paulistana (Piauí). O material foi recebido na forma não expandida, com uma granulometria denominada "fina" segundo o fornecedor. A resina de PP escolhida foi a Polibrasil VS-6100 (homopolímero) com um índice de fluidez de 20,0 g/10min e uma densidade 0,905 $\mathrm{g} / \mathrm{cm}^{3}$, foi utilizado também um PP modificado Polybond 3200 PP-g-AM (PP grafitizado com anidrido maleico) como agente de compatibilização, dito PP possui um grau de funcionalização de $0,5 \%$ em peso de anidrido maleico, índice de fluidez de $115 \mathrm{~g} / 10 \mathrm{~min}$ e uma densidade de $0,91 \mathrm{~g} / \mathrm{cm}^{3}$.

\subsection{Técnicas de caracterização}

\subsubsection{Análise química por fluorescência de raios X (FRX)}

A analise química da vermiculita foi realizada utilizando a técnica semiquantitativa de fluorescência de raios X, fazendo uso do equipamento PHILIPS, modelo PW2404, disponível no Laboratório de Caracterização Tecnológica (LCT) do Departamento de Engenharia de Minas e de Petróleo (PMI) da Escola Politécnica da Universidade de São Paulo (EPUSP).

\subsubsection{Análise de difração de raios X (DRX)}

A técnica de difratometria de raios $\mathrm{X}$ foi empregada neste trabalho com o objetivo de identificar as fases cristalinas presentes na vermiculita natural. Os ensaios de difração de raios X foram realizados em um difratômetro Philips X'PERT MPD utilizando a radiação do cobre $\mathrm{K} \alpha(\lambda=1.5418 \AA)$, com passos de $0,02^{\circ}$ e tempo de $1 \mathrm{~s}$ de permanência, disponível no Laboratório de Matérias-Primas Particuladas e Sólidos Não-Metálicos (LMPSol), da EPUSP.

\subsubsection{Ensaios de inchamento em água}

O ensaios de inchamento de foram adotados com o objetivo de verificar o grau de inchamento osmótico no meio aquoso das vermiculitas tratadas a maneira de avaliar o efeito dos tratamentos utilizados, bem como da agitação mecânica. Os ensaios realizados estão baseados no procedimento descrito por Foster (1953), usado 
para bentonitas sódicas, que consiste na adição de $1 \mathrm{~g}$ de argila seca e moída numa granulometria compreendia entre as peneiras \#20 $(850 \mu \mathrm{m})$ e \#40 $(425 \mu \mathrm{m})$, em pequenas quantidades a uma proveta graduada contendo $100 \mathrm{~mL}$ de água destilada, após 24 horas da adição mede-se o volume de sedimento na graduação da proveta, o valor obtido é expressado mililitros por grama $(\mathrm{mL} / \mathrm{g})$.

Devido ao baixo inchamento que apresentam as vermiculitas, foram utilizados $5 \mathrm{~g}$ como massa inicial em todos os ensaios, isto com objetivo de facilitar a leitura do inchamento, no entanto, o volume aparente final continua sendo expresso em $\mathrm{mL} / \mathrm{g}$. A granulometria das amostras foi modificada também, isto devido a que a granulometria descrita no procedimento de Foster (1953) resulta relativamente grande em comparação as granulometrias das cargas normalmente utilizadas na preparação de compósitos poliméricos. A granulometria escolhida esta compreendia entre as peneiras \#100 $(150 \mu \mathrm{m})$ e \#250 $(63 \mu \mathrm{m})$. O procedimento adotado é descrito através dos seguintes passos:

- Pesar 5g de vermiculita seca ao ar, a temperatura ambiente no tamanho de partículas escolhida.

- Transferir para um béquer de pyrex de $250 \mathrm{~mL}$.

- Efetuar o tratamento das amostras com a solução escolhida, na molaridade e no volume desejados.

- Terminado o tempo de tratamento (144 horas), lavar varias vezes o material com água destilada, filtrar e deixar na estufa a $60^{\circ} \mathrm{C}$ a noite toda.

- Tirar o material seco da estufa e desaglomerar num almofariz.

- Adicionar o material em pequenas quantidades em uma proveta graduada contendo $100 \mathrm{ml}$ de água destilada.

- Após 24 horas da adição fazer a medição do volume do sedimento.

Baseando-se no fato do inchamento macroscópico estar associado à formação de uma dupla camada difusa, a qual é formada pelas cargas dos íons positivos e negativos da solução adjacente às partículas, foi adotado um segundo procedimento para avaliar os inchamentos das amostras tratadas sem lavagem, isto, com o objetivo de determinar a influência dos íons restantes na solução no processo de formação do inchamento. O procedimento utilizado é descrito no trabalho de Vieira-Coelho (1986) e consta dos seguintes passos: 
- Pesar 5g de vermiculita seca ao ar, a temperatura ambiente na granulometria escolhida.

- Transferir para um béquer de pyrex de $250 \mathrm{~mL}$.

- Efetuar o tratamento das amostras com a solução do sal escolhida, na molaridade e no volume desejados.

- Terminado o tempo de tratamento, adicionar $50 \mathrm{~mL}$ de água destilada no béquer.

- Transferir o conteúdo do béquer, com auxilio de uma pisseta para uma proveta graduada de $100 \mathrm{~mL}$.

- Completar o volume graduado da proveta com água destilada.

- Após 24 horas da adição fazer a medição do volume do sedimento.

\subsubsection{Determinação da capacidade de troca catiônica}

Para a determinação da CTC das amostras estudadas foi utilizado o método de acetato de amônio, que consiste no deslocamento dos cátions trocáveis da argila pelo cátion $\mathrm{NH}_{4}^{+}$. Para a determinação do conteúdo de nitrogênio nas amostras foi utilizado o aparelho destilador de Kjeldahl, disponível no LMPSol. Os reagentes utilizados, assim como os procedimentos e cálculos são descritos em detalhe no apêndice $\mathrm{A}$.

\subsubsection{Distribuição granulométrica por dispersão de laser}

A utilização desta técnica teve por objetivo a determinação da distribuição do tamanho das partículas das amostras, assim como a monitoração do grau de desaglomeração causado pelos tratamentos e pela agitação mecânica nas partículas de vermiculita. O equipamento utilizado foi um Malvern Mastersizer X, disponível no Laboratório de Simulação e Controle de Processos (LSCP) da EPUSP. As amostras foram dispersadas em água deionizada, sem o uso de dispersantes, e sob a ação do ultra-som durante 3 minutos para ajudar a desaglomeração das partículas. 


\subsection{Preparação do material}

\subsubsection{Moagem}

A moagem da vermiculita foi realizada através do moinho de facas Thomas-Willey modelo 4 do LMPSol. O material moído foi separado em três distribuições de granulometria distintas, sendo utilizadas três peneiras ABTN na seguinte ordem \#100 \#250 e \#325 com aberturas $150 \mu \mathrm{m}, 63 \mu \mathrm{m}$ e $45 \mu \mathrm{m}$ respectivamente. O material selecionado para este trabalho foi aquele que ficou retido na segunda peneira.

\subsubsection{Tratamentos}

No presente trabalho foram estudadas amostras de vermiculita que foram submetidas a dois tratamentos distintos, os quais tem como objetivo produzir uma queda de carga nas camadas e em decorrência facilitar a desaglomeração dos agregados na presença de agitação mecânica. Para fins de comparação, foi preparada também uma amostra de vermiculita a ser utilizada como "prova em branco" (PB). Essa amostra foi preparada em água deionizada e seca nas mesmas condições que as amostras tratadas.

\subsubsection{Tratamentos com sais inorgânicos}

Foram realizados dois tratamentos salinos utilizando $\mathrm{LiCl}$ e NaCl. Ambos tratamentos seguiram o mesmo procedimento, que consistiu na adição de $25 \mathrm{~mL}$ da solução aquosa do sal escolhido, na molaridade e concentração desejada, a um béquer de $250 \mathrm{~mL}$ contendo $5 \mathrm{~g}$ de vermiculita. Em seguida o béquer foi levado a estufa a $60^{\circ} \mathrm{C}$ e agitado cada 30 minutos, após 4 horas, colocou-se as amostras numa estufa a $90^{\circ} \mathrm{C}$ e deixou-se por 144 horas para garantir a secagem. Após a secagem o material foi lavado com água deionizada, filtrado e então seco em estufa a $60^{\circ} \mathrm{C}$ a noite toda.

\subsubsection{Tratamentos com ácido clorídrico}

O tratamento consistiu na imersão de $25 \mathrm{~g}$ de vermiculita num erlenmeyer contendo 1000mL de uma solução 2M de ácido clorídrico. Em seguida, colocou-se o erlenmeyer no agitador magnético e deixou-se agitar durante diferentes períodos de tempo a temperatura ambiente. Após agitação, a amostra foi lavada com água deionizada várias vezes a fim de remover todas as impurezas e as substâncias solúveis provenientes do tratamento. Com o mesmo propósito foi realizado um controle dos íons 
cloro utilizando uma solução de $\mathrm{AgNO}_{3}$. O controle consistiu na adição de entre 5 a 10 gotas de uma solução $0,1 \mathrm{M}$ de $\mathrm{AgNO}_{3}$ na solução de lavagem, a formação de um precipitado branco (cloreto de prata) sinalizou a presença de íons cloro. A suspensão foi lavada até o precipitado não ser observado. Finalmente o material é filtrado e seco em estufa a $60^{\circ} \mathrm{C}$ a noite toda.

\subsubsection{Agitação mecânica}

Para realizar a desaglomeração mecânica dos aglomerados de partículas de vermiculita e talvez até mesmo conseguir-se alguma delaminação dessas partículas, foi utilizado o homogeneizador dispersor de alta energia de cisalhamento Heidolph Diax 900 disponível no Laboratório de Polímeros da EPUSP. Primeiramente pesou-se 5g de amostra tratada, em seguida a amostra foi imersa num erlenmeyer contendo 330mL de água deionizada. A suspensão resultante foi colocada no homogeneizador dispersor a uma velocidade de 24000rpm durante 10 minutos. Após a agitação mecânica o material foi centrifugado, lavado várias vezes com etanol absoluto e seco em estufa a $60^{\circ} \mathrm{C}$ a noite toda.

\subsection{Preparação dos materiais compósitos}

\subsubsection{Processo de mistura dos compósitos}

Com o objetivo de estudar a influência da adição de vermiculita sem tratamento assim como da vermiculita tratada acidamente nas propriedades mecânicas do compósito, foram preparados compósitos com duas formulações distintas. Além disso, foi preparada uma amostra contendo PP e PP-g-AM nas mesmas condições de processamento como prova em branco. Na Tabela 3.1 mostra-se as formulações preparadas.

Tabela 3.1: Identificação das amostras

\begin{tabular}{lcccc}
\hline & \multicolumn{4}{c}{ Porcentagem em peso } \\
Nomenclatura & PP & PP-g-AM & Vermiculita & Tratamento \\
\hline PP/PP-g-AM & 70 & 20 & 0,0 & Sem trat. \\
PP/PP-g-AM/10\%VMT ST & 70 & 20 & 10,0 & Sem trat. \\
PP/PP-g-AM/10\%VMT CT & 70 & 20 & 10,0 & $5 \mathrm{~h} 2 \mathrm{M} \mathrm{HCl}$ \\
\hline
\end{tabular}

Para realizar a mistura e homogeneizado do material foi utilizado o equipamento reômetro de torque Haake disponível no laboratório de polímeros da EPUSP. As 
amostras dos compósitos foram preparadas no misturador interno de dois rotores contra-rotatórios, empregando uma temperatura de $180^{\circ} \mathrm{C}$, a uma velocidade de rotação de $80 \mathrm{rpm}$. O processo de mistura consistiu de duas etapas, primeiramente o PP e o PP-g-AM são misturados durante 5 minutos, após este período de tempo a vermiculita foi adicionada e misturada por 10 minutos nas mesmas condições. Em seguida o material resultante foi retirado da câmera de mistura e resfriado em água. Para a obtenção dos pellets o material obtido no misturador foi seco e submergido em nitrogênio liquido a fim de facilitar a moagem. Finalmente o material foi picotado em um moinho de facas.

\subsubsection{Processo de injeção dos compósitos}

Para a injeção dos corpos de prova foi utilizada a mini injetora HAAKE MiniJet disponível no Laboratório de Macromoléculas (LEM) da EPUSP, as temperaturas utilizadas foram de $200^{\circ} \mathrm{C}$ e $45^{\circ} \mathrm{C}$ para o cilindro de aquecimento e para o molde respectivamente. Os pellets foram colocados no cilindro de aquecimento por 10 minutos. Após a fusão do material, colocou-se o cilindro na mini injetora para injetar o material a uma pressão de 800 bar. Os corpos de prova foram injetados na forma de gravatas (tipo V) de acordo com as especificações da norma ASTM D638.

\subsubsection{Análise por microscopia óptica}

A análise de microscópica óptica foi realizada no laboratório de microscopia do Departamento de Engenharia Metalúrgica e de Materiais (PMT) da EPUSP. As amostras dos compósitos contendo vermiculita tratada e não tratada foram observadas em uma lupa estereoscopia de laboratório. As micrografias foram obtidas com o auxílio de uma câmera digital acoplada ao instrumento e a escala das micrografias foi determinada utilizando uma régua milimetrada. 


\section{RESULTADOS E DISCUSSÃO}

Este capítulo está dividido em três tópicos. Primeiramente serão apresentados e discutidos os resultados obtidos na caracterização da matéria-prima, seguido da discussão dos resultados da avaliação dos tratamentos químicos e, finalmente, no tópico avaliação dos compósitos, serão discutidos os efeitos da adição de vermiculita à matriz polimérica.

\subsection{Caracterização da matéria-prima}

\subsubsection{Análise de distribuição granulométrica}

A distribuição granulométrica do material tal como recebido foi determinada por peneiramento a seco, método que consiste em colocar uma massa conhecida de material em um conjunto de peneiras de aberturas conhecidas, sob ação de vibração mecânica, sendo que após o peneiramento, a massa retida em cada peneira é medida. No presente trabalho o peneiramento foi realizado fazendo uso de uma série de peneiras ABTN na seguinte ordem \#20 \#35 \#48 \#100 \#250 e \#325 com aberturas $850 \mu \mathrm{m}, 500 \mu \mathrm{m}, 300 \mu \mathrm{m}, 150 \mu \mathrm{m}, 63 \mu \mathrm{m}$ e $45 \mu \mathrm{m}$ respectivamente. Os resultados da análise de distribuição granulométrica mostraram que ao redor de $90 \%$ do material ficou distribuído entre as peneiras \#20 $(800 \mu \mathrm{m})$ e \#35 $(500 \mu \mathrm{m})$.

\subsubsection{Análise química}

A Composição química da vermiculita de Paulistana (Piauí) obtida pela técnica de fluorescência de raios X, é apresentada na Tabela 4.1 junto com as composições químicas de vermiculitas dos estados de Goiás (MARCOS; ARANGO; RODRIGUEZ, 2009), Bahia (RosenburG, 1972) e Paraíba (UGARTE; SAMPAiO; FRAnÇA, 2005). Os resultados revelam uma elevada quantidade de óxidos de alumínio, silício e de magnésio característicos da vermiculita, além apresenta na sua composição de $6 \%$ 
de óxidos de ferro e teores abaixo de 2,0 \% em óxidos de cálcio, potássio, sódio, manganês e titânio. Além disso a perda ao fogo indica um baixo teor de matéria orgânica na amostra.

Tabela 4.1: Composição química de vermiculitas brasileiras.

\begin{tabular}{ccccc}
\hline & \multicolumn{4}{c}{ Percentual em massa $(\%)$} \\
Oxidos & $\begin{array}{c}\text { Paulistana } \\
\text { Catalão }\end{array}$ & $\begin{array}{c}\text { Brumado } \\
(\mathrm{GI})\end{array}$ & $\begin{array}{c}\text { Santa Luzia } \\
(\mathrm{PB})\end{array}$ \\
\hline $\mathrm{SiO}_{2}$ & 44,3 & 40,67 & 36,80 & 42,8 \\
$\mathrm{MgO}$ & 25,7 & 18,05 & 22,59 & 19,9 \\
$\mathrm{Al}_{2} \mathrm{O}_{3}$ & 11,8 & 11,51 & 21,68 & 6,8 \\
$\mathrm{Fe}_{2} \mathrm{O}_{3}$ & 6,46 & 9,58 & 1,26 & 6,7 \\
$\mathrm{CaO}$ & 1,54 & 0,03 & 2,64 & 0,56 \\
$\mathrm{TiO}_{2}$ & 0,63 & 0,79 & 0,49 & 0,86 \\
$\mathrm{Na}_{2} \mathrm{O}$ & 0,07 & 0,12 & 1,03 & 1,0 \\
$\mathrm{MnO}$ & 0,03 & 0,08 & traços & 0,11 \\
$\mathrm{~K}_{2} \mathrm{O}$ & 1,63 & 1,07 & 5,79 & 4,6 \\
Perda ao fogo & 6,22 & 18,06 & 6,75 & 15,80 \\
\hline
\end{tabular}

\subsubsection{Difração de raios $\mathrm{X}$}

Com o objetivo de verificar as fases cristalinas da vermiculita, assim como detectar impurezas, foram analisadas três amostras de vermiculita com diferentes granulometrias. A Figura 4.1 apresenta os padrões de difração da vermiculita na granulometria tal como foi recebida e, após moagem, das frações compreendidas entre as malhas \#100 e \#250 e entre \#250 e \#325.

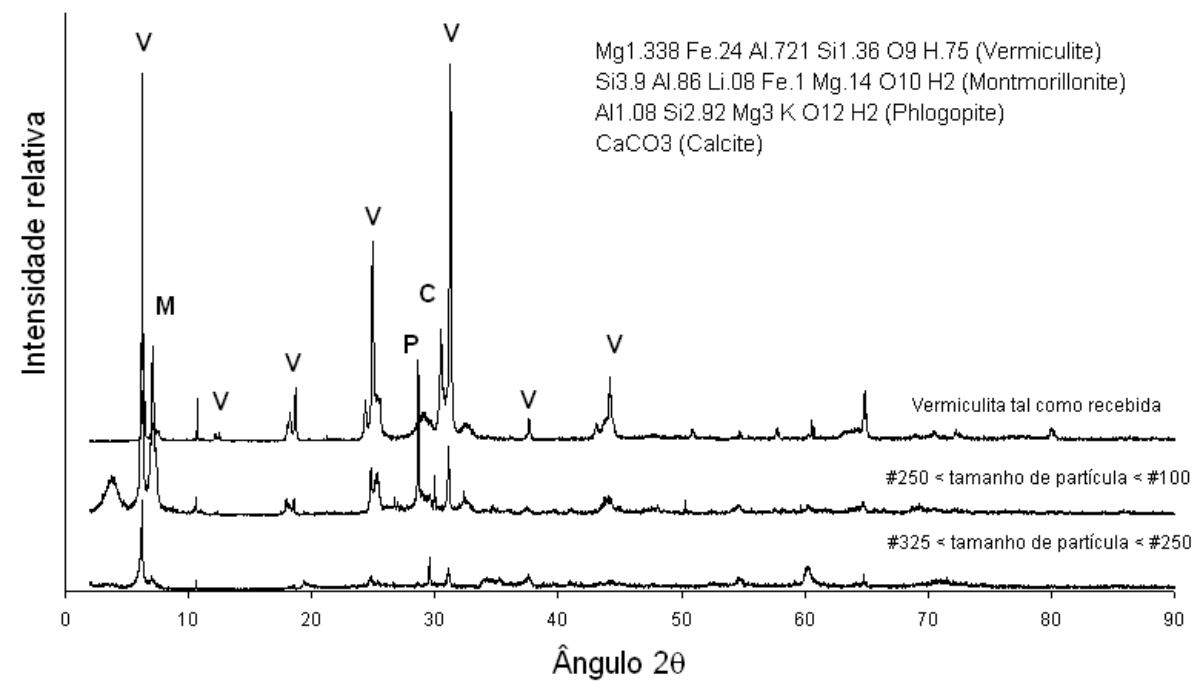

Figura 4.1: Curvas de difração da vermiculita tal como recebida e nas frações compreendidas entre as malhas s\#100 e \#250 e entre \#250 e \#325. 
Verificou-se através das curvas de difração apresentadas na Figura 4.1, que a amostra estudada está constituída principalmente por vermiculita. As três curvas de difração de raios $\mathrm{X}$ apresentam os picos característicos de vermiculita a $6,23^{\circ}$, $12,37^{\circ}, 18,69^{\circ}, 24,77^{\circ} \mathrm{e} 31,07^{\circ}$ correspondentes às distâncias $14,18,7,16,4,75,3,59 \mathrm{e}$ $2,88 \AA$, respectivamente. Outros picos a $7,07^{\circ}, 28,60^{\circ}$ e a $29,42^{\circ}$ mostram a provável presença de montmorilonita e flogopita e calcita, respectivamente.

\subsection{Avaliação dos tratamentos}

\subsubsection{Ensaios de inchamento em água}

\subsubsection{Ensaios para a determinação das concentrações das soluções aquo- sas de $\mathrm{LiCl}$ e $\mathrm{NaCl}$}

A fim de determinar as concentrações de cloretos de Lítio e Sódio que provocam maior inchamento, foram realizados ensaios de inchamento das amostras de vermiculita variando a concentração de $\mathrm{LiCl}$ e $\mathrm{NaCl}$ na solução de tratamento. A Figura 4.2 mostra os índices de inchamento em água para as amostras de vermiculita tratadas com diferentes concentrações de $\mathrm{LiCl}$ e $\mathrm{NaCl}$, respectivamente. Para facilitar as medições, as amostras tratadas nesta etapa não foram lavadas, portanto, foi utilizado o segundo procedimento descrito na seção 3.3.3 deste trabalho.

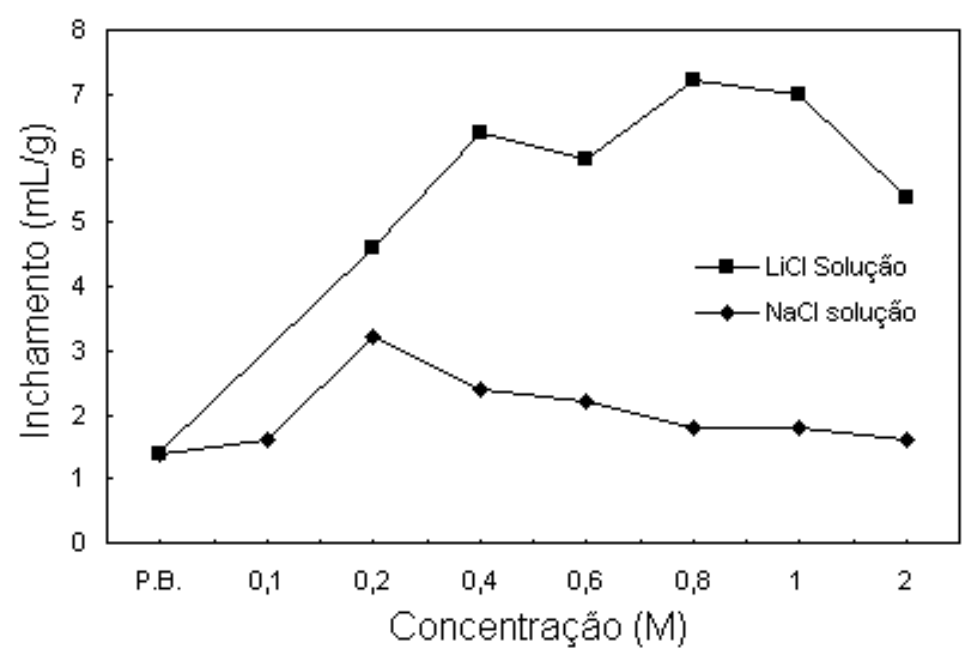

Figura 4.2: Índices de inchamento em água para as amostras de vermiculita tratadas com diferentes concentrações de $\mathrm{LiCl}$ e $\mathrm{NaCl}$.

Verificou-se na Figura 4.2 que efetivamente amostras de vermiculita tratadas com soluções de LiCl após 144 horas permitindo a secagem da solução de tratamento, levam a valores de inchamento mais pronunciados, o inchamento máximo 
foi observado na amostra tratada com solução $0,8 \mathrm{M}$ de $\mathrm{LiCl}$, equivalente a $0,168 \mathrm{~g}$ de $\mathrm{LiCl} / \mathrm{g}$ de vermiculita, atingindo um valor de $6,6 \mathrm{~mL} / \mathrm{g}$ de vermiculita, o equivalente aproximadamente a 5 vezes o inchamento da vermiculita sem tratamento, no entanto, não foi possível atingir valores de inchamento similares a os descritos no trabalho de Vieira-Coelho (1986) para tratamentos com $\mathrm{LiCl}$, ao redor de 7 vezes o volume da prova em branco.

Pode-se observar na Figura 4.2 que amostras tratadas com soluções de $\mathrm{NaCl}$ durante 144 horas permitindo a secagem da solução de tratamento, levam a inchamentos maiores que amostras sem tratar, no entanto, os inchamentos observados para este tratamento são menores que os valores obtidos utilizando tratamentos com soluções de LiCl. O inchamento máximo foi de $3,2 \mathrm{~mL} / \mathrm{g}$ de vermiculita e se deu na amostra tratada com concentração $0,2 \mathrm{M}$ de $\mathrm{NaCl}$, equivalente a $0,058 \mathrm{~g}$ de $\mathrm{NaCl} / \mathrm{g}$ de vermiculita.

\subsubsection{Ensaios para a determinação do tempo de tratamento ácido}

Com o objetivo de determinar o tempo de exposição à solução ácida que leve à obtenção de maiores valores de inchamento, foram realizados ensaios de inchamento em água de amostras de vermiculita tratadas com ácido clorídrico utilizando diferentes tempos de tratamento. Devido a lavagem ser inevitável neste tratamento, foi utilizado o primeiro procedimento descrito na seção 3.3.3. Na Figura 4.3 são apresentados os índices de inchamento em água das amostras de vermiculita tratadas com $\mathrm{HCl}$.

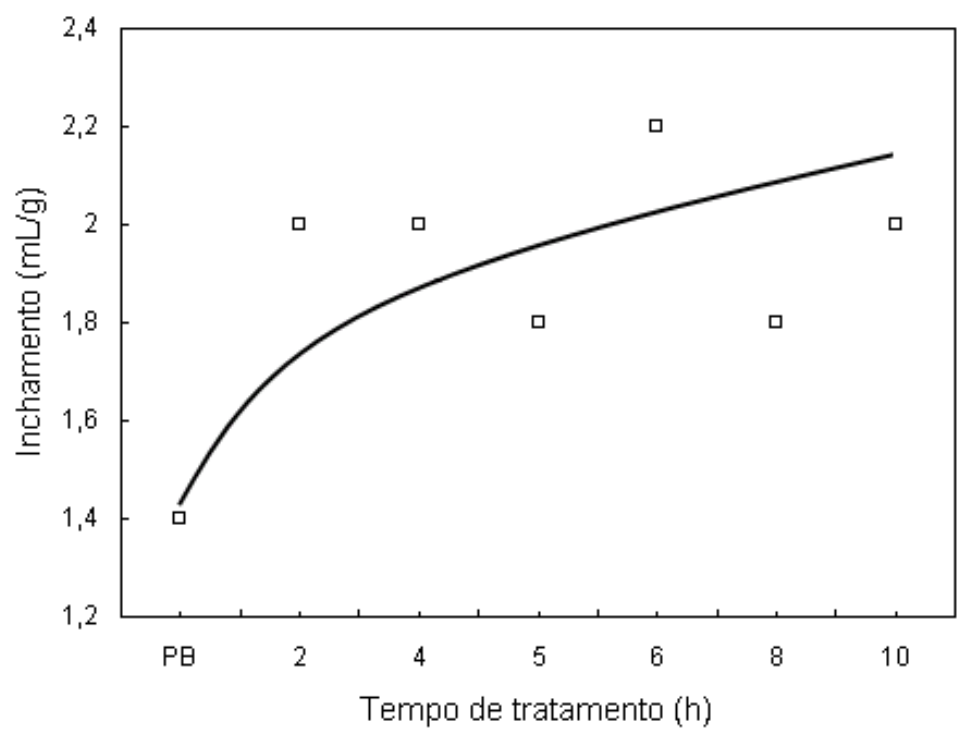

Figura 4.3: Índices de inchamento em água para as amostras de vermiculita tratadas com $\mathrm{HCl}$. 
Os dados na Figura 4.3 mostram que as amostras tratadas com solução $2 \mathrm{M}$ de $\mathrm{HCl}$ sem importar o tempo de tratamento, geram poucas mudanças no inchamento osmótico da vermiculita. Devido a este fato adotou-se a CTC das amostras como parâmetro para determinar o tempo de tratamento, os resultados são discutidos na seção 4.2.2.2 deste mesmo capitulo.

\subsubsection{Capacidade de troca catiônica}

A determinação dos valores de CTC das amostras tratadas foi realizada com o propósito de estimar o grau de alteração causada pelos tratamentos utilizados. As determinações foram feitas em duplicata e conforme o procedimento descrito no anexo A.

\subsubsection{Determinação da CTC das amostras tratadas com sais inorgânicos}

Foi realizada a determinação da CTC das amostras de vermiculita tratadas com $\mathrm{LiCl}$ e $\mathrm{NaCl}$ que apresentaram maiores valores de inchamento, foram escolhidas as amostras tratadas com $0,8 \mathrm{M}$ e $0,2 \mathrm{M}$ de $\mathrm{LiCl}$ e $\mathrm{NaCl}$, respectivamente. Os resultados estão apresentados na Tabela 4.2 .

Tabela 4.2: Resultados da CTC das amostras tratadas com sais inorgânicos

\begin{tabular}{lc}
\hline Amostra & $\mathrm{CTC} 110^{\circ} \mathrm{C}(\mathrm{meq} / 100 \mathrm{~g})$ \\
\hline amostra sem tratar & 110 \\
amostra tratada $0,8 \mathrm{M} \mathrm{LiCl}$ & 119 \\
amostra tratada $0,2 \mathrm{M} \mathrm{NaCl}$ & 109 \\
\hline
\end{tabular}

Os resultados apresentados na Tabela 4.2 mostram pouca variação nos valores de CTC para as vermiculitas tratadas, isto poderia levar inicialmente a supor que não foi possível gerar condições adequadas para conseguir a penetração dos cátions lítio e sódio na estrutura da vermiculita, posto que, os valores de queda de CTC esperados estariam na ordem de $15 \%$ a $30 \%$ como são descritos no trabalho de VieiraCoelho (1986), contudo, as amostras tratadas reportaram os índices mais altos de inchamento, o que significaria que efetivamente os cátions Li e Na penetraram na estrutura da vermiculita, portanto, é possível que tenham sido conseguidos valores de queda da CTC muito pequenos, que poderiam estar sujeitos à margem de variabilidade do método, outra possibilidade que não se descarta é a presença de algum tipo de erro durante a determinação. 


\subsubsection{Determinação da CTC das amostras tratadas com ácido clorídrico}

Foi realizada a determinação da CTC de duas amostras de vermiculita tratadas com soluções $2 \mathrm{M}$ de $\mathrm{HCl}$ por diferentes tempos de tratamento, para fins de comparação foi determinada também a CTC de uma amostra sem tratamento. Os resultados são apresentados na Tabela 4.3.

Tabela 4.3: Resultados da CTC das amostras tratadas com ácido clorídrico

\begin{tabular}{lc}
\hline Amostra & $\mathrm{CTC} 110^{\circ} \mathrm{C}(\mathrm{meq} / 100 \mathrm{~g})$ \\
\hline amostra sem tratar & 110 \\
amostra tratada 2M HCl por 5 horas & 70 \\
amostra tratada 2M HCl por 8 horas & 45 \\
\hline
\end{tabular}

Na Figura 4.4 são apresentados os valores de CTC obtidos, relacionados com os índices de inchamento em água das amostras de vermiculita tratadas com soluções $2 \mathrm{M}$ de $\mathrm{HCl}$ por diferentes tempos de tratamento.

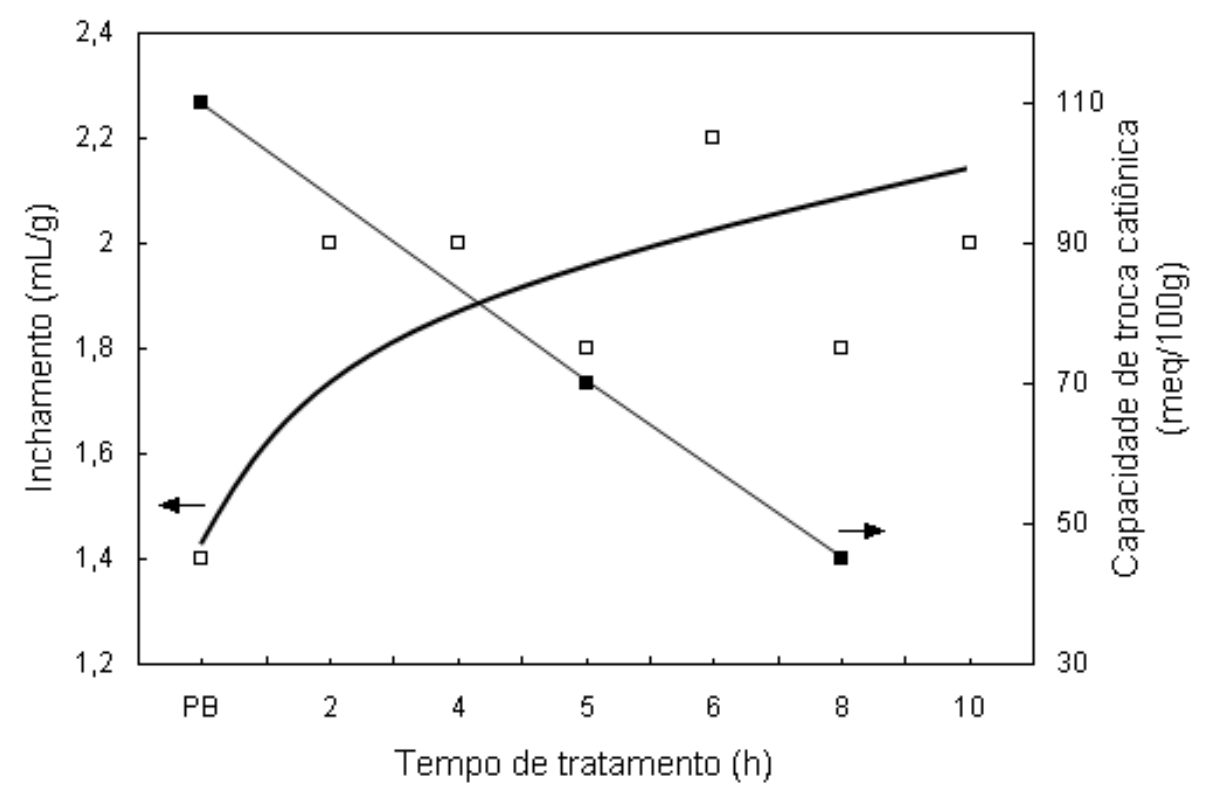

Figura 4.4: Índices de inchamento em água e valores de CTC para as amostras de vermiculita tratadas com $\mathrm{HCl}$.

Na Figura 4.4 pode-se observar que as amostras de vermiculitas tratadas com solução $2 \mathrm{M}$ de $\mathrm{HCl}$, apresentam uma diminuição constante na CTC conforme aumentam os tempos de tratamento, nos tempos de tratamento mais longos, isto é, para tratamentos ao redor de 8 horas foram observados valores de CTC muito baixos se comparados com esmectitas. Já tratamentos com períodos de exposição de 5 horas apresentam valores de CTC semelhantes aos de esmectitas. Como é sabido as esmectitas desaglomeram facilmente em presença de água, baseados neste fato inferiu-se 
que tempos de tratamento de 5 horas, levariam a comportamentos similares às esmectitas e portanto a maior desaglomeração das partículas de vermiculita.

\subsubsection{Comparação dos inchamentos após a agitação mecânica}

Com o objetivo de avaliar a influência da agitação mecânica, assim como dos íons restantes na solução no processo de formação do inchamento, amostras de vermiculita tratadas com $\mathrm{LiCl}$ e $\mathrm{NaCl}$ lavadas e não lavadas foram submetidas a agitação mecânica conforme o procedimento descrito no item 3.4.3. Os inchamentos foram medidos antes e após o processo de agitação mecânica, adicionalmente preparou-se uma amostra de vermiculita sem tratamento como prova em branco. Na Figura 4.5 mostra-se os inchamentos das vermiculitas tratadas com sais inorgânicos antes e depois a agitação mecânica com lavagem e sem lavagem.

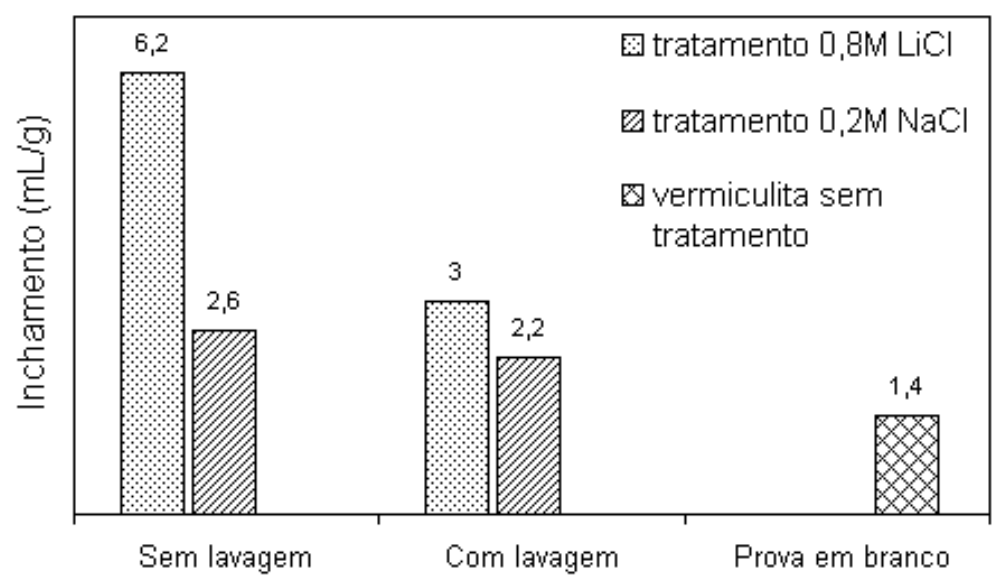

Figura 4.5: Comparação dos inchamentos das amostras de vermiculita tratadas após agitação mecânica.

Na Figura 4.5 observa-se uma diminuição no inchamento das amostras tratadas com sais inorgânicos após a lavagem, isto sugere que os íons restantes da solução de tratamento intervém na formação da dupla camada da partícula de vermiculita, portanto, a ausência dos íons levaria a uma queda no potencial elétrico, e em conseqüência uma queda no inchamento. Devido a este fato foi adotado o processo de lavagem para as amostras tratadas com sais inorgânicos. Embora maiores valores de inchamento podem ser obtidos evitado o processo de lavagem, o propósito deste estudo é avaliar a influência da adição vermiculita em uma matriz polimérica, portanto a presença de íons restantes da solução de tratamento podem levar a equívocos na avaliação dos compósitos. 
Observou-se um comportamento interessante nas amostras tratadas acidamente, ditas amostras apresentaram elevados volumes de sedimento como conseqüência da agitação mecânica, a fim de estimar ditos volumes as amostras foram deixadas sedimentar em 100mL de água deionizada antes do processo de lavagem e secagem, após 24 horas o volume de sedimento foi medido. Para efeito de comparação foi realizado o mesmo procedimento para amostras tratadas com $\mathrm{LiCl}$ e $\mathrm{NaCl}$. Os resultados são apresentados na Figura 4.6.

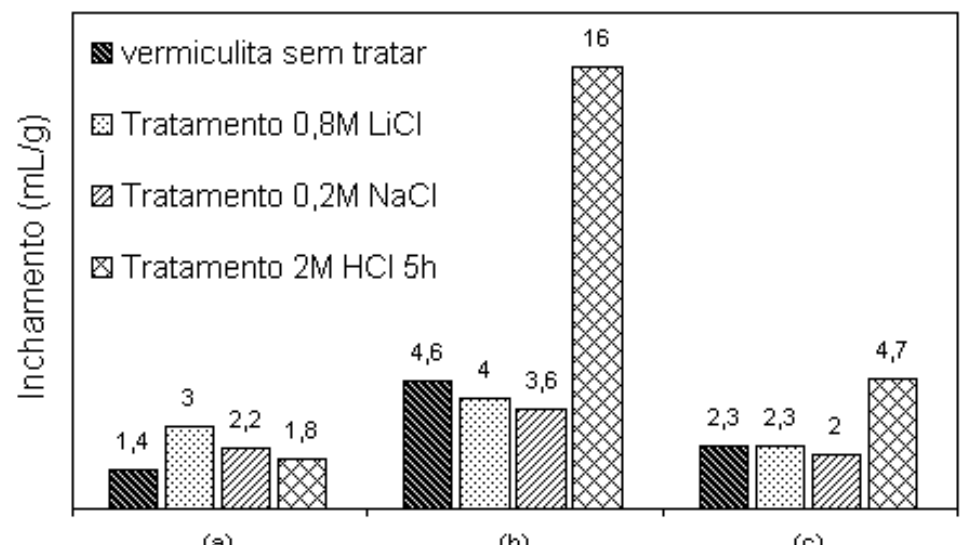

Figura 4.6: Comparação do inchamento das amostras de vermiculita tratadas: (a) Inchamento em água após o tratamento com soluções aquosas; (b) Volume de sedimento após 24 horas a agitação mecânica; (c) Inchamento em água após a agitação mecânica e a secagem das amostras de vermiculita tratadas.

Os resultados apresentados na Figura 4.6 sugerem que tratamentos com soluções 2M de $\mathrm{HCl}$ por períodos de 5 horas, produzem condições adequadas para alcançar altos graus de desaglomeração da vermiculita após a agitação mecânica, sendo registrados inchamentos de até 11 vezes a prova em branco. Contudo, as mesmas amostras apresenta valores inferiores de inchamento após o processo de centrifugação e secagem registrando valores ao redor de 3 vezes a prova em branco, isto comportamento sugere que o tratamento ácido por um tempo de exposição de 5 horas não tenha causado uma queda suficiente na carga das camadas da vermiculita, e em conseqüência, as partículas tenham aglomerado novamente durante o processo de secagem. Por outro lado, este fenômeno de aglomeração durante a secagem é observado com menor intensidade nos outros tratamentos e mesmo na vermiculita sem tratamento. 


\subsubsection{Distribuição de tamanho de partícula}

Primeiramente, foi realizada a determinação da distribuição granulométrica das amostras de vermiculita sem tratamento (prova em branco) antes e após agitação mecânica como prova de comparação. Adicionalmente, a maneira de observar o grau de influência do tempo de agitação, foi submetida uma amostra sem tratar a agitação mecânica utilizando o dobro do tempo de agitação escolhido. A Figura 4.7 apresenta a distribuição granulométrica das amostras de vermiculita sem tratamento submetidos a 10 e 20 minutos de agitação mecânica.

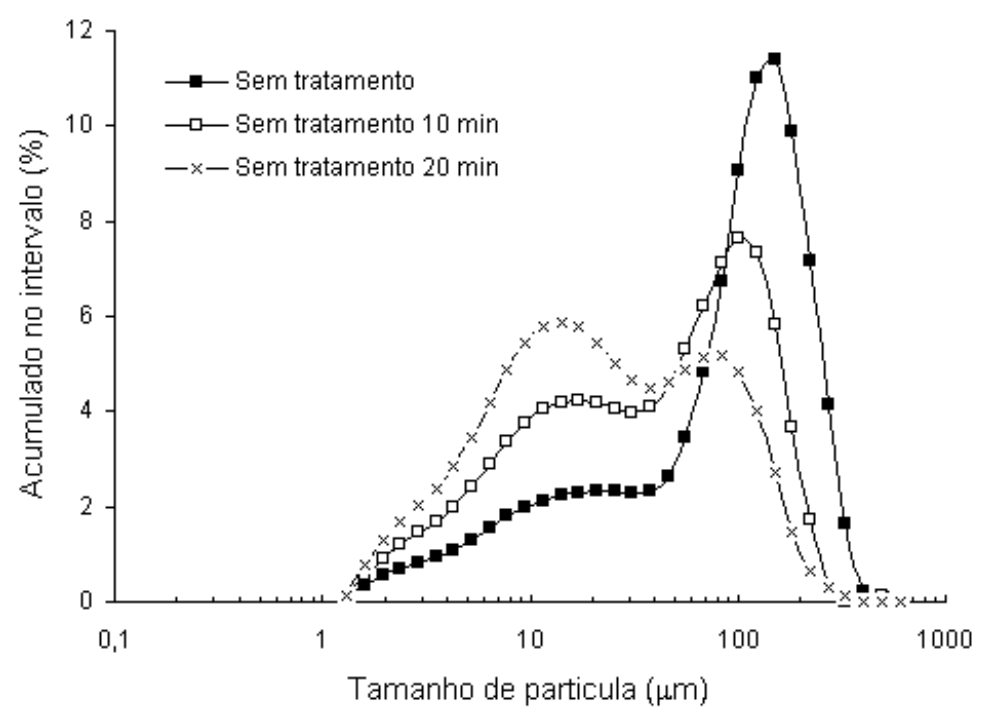

Figura 4.7: Curvas de distribuição granulométrica de amostras sem tratamentos submetidas a 10 e 20 minutos de agitação mecânica.

Na Figura 4.7 verificou-se que tempos de agitação mais longos contribuem para a obtenção de menores distribuições de tamanho de partícula, isto pode ser observado no crescimento na moda esquerda das curvas de distribuição granulométrica.

\subsubsection{Determinação da granulométrica após a agitação mecânica das amostras tratadas com sais inorgânicos}

A determinação das distribuições granulométricas das amostras tratadas foi realizada antes e depois a agitação mecânica. Também, foram realizadas determinações da distribuição granulométrica dos tratamentos salinos com e sem lavagem, a fim de observar a influência dos íons restantes na solução de tratamento no processo de agitação. A Figura 4.8 e a Figura 4.9 mostram as curvas de distribuição granulométrica para tratamentos com cloreto de lítio e sódio, respectivamente, antes e depois da agitação mecânica. 


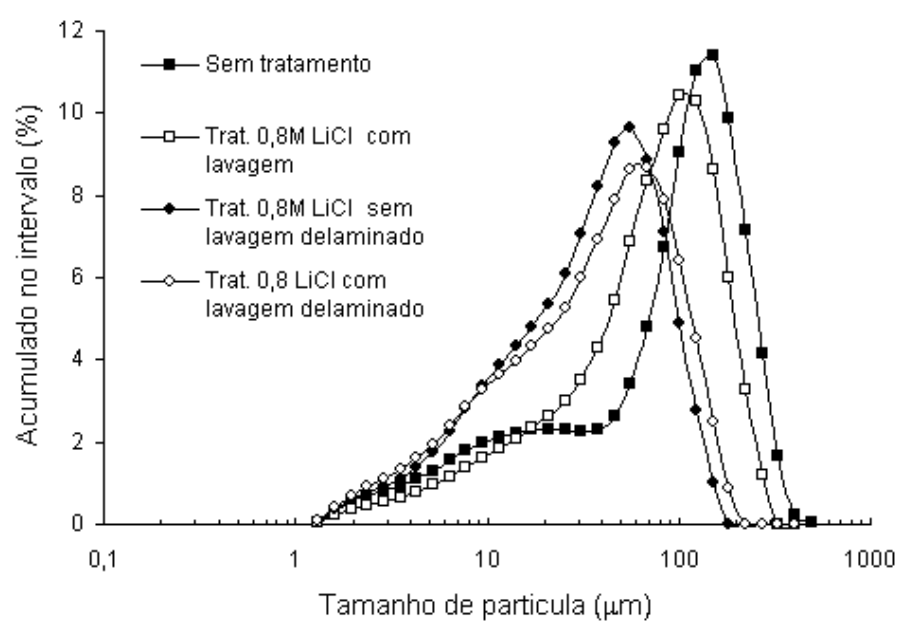

Figura 4.8: Curvas de distribuição granulométrica para amostras tratadas com LiCl após agitação mecânica.

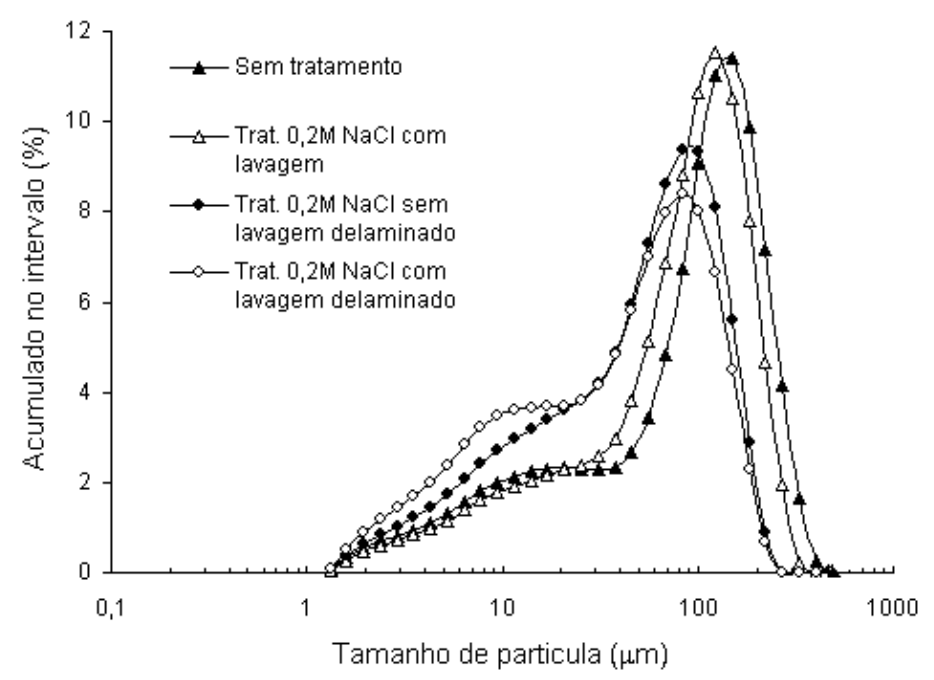

Figura 4.9: Curvas de distribuição granulométrica para amostras tratadas com $\mathrm{NaCl}$ após agitação mecânica.

A Figura 4.8 e a Figura 4.9 mostram uma pequena diminuição nos tamanho de partículas, devido ao tratamento salino, esse aumento é expresso pelos valores dos diâmetros médio, de $101,8 \mu \mathrm{m}$ para a amostra sem tratamento e $85,7 \mu \mathrm{m}$ e $94,4 \mu \mathrm{m}$ para as amostras tratadas com $\mathrm{LiCl}$ e NaCl, respectivamente. No entanto, a agitação mecânica produz uma diminuição maior no tamanho de partículas atingindo valores no diâmetro médio de partículas de $49,4 \mu \mathrm{m}$ e $58,4 \mu \mathrm{m}$ para tratamentos com LiCl e $\mathrm{NaCl}$, respectivamente. Observou-se, também que a lavagem das amostras produz uma pequena variação no tamanho das partículas, contudo, a presença de íons restantes na solução de tratamento, não afeta de forma marcante a desaglomeração das partículas de vermiculita. 


\subsubsection{Determinação da granulométrica após a agitação mecânica das amostras tratadas com ácido clorídrico}

A Figura 4.10 apresenta a distribuição do tamanho de partículas para amostras tratadas com uma solução $2 \mathrm{M}$ de ácido clorídrico por 5 horas, antes e depois a agitação mecânica.

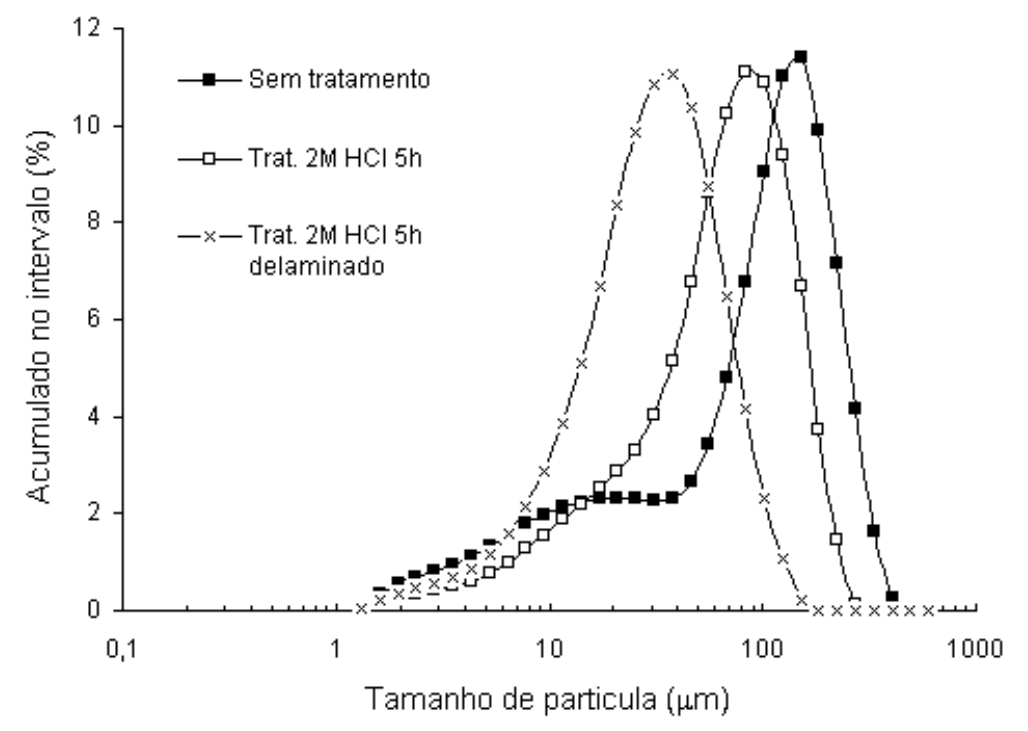

Figura 4.10: Curvas de distribuição granulométrica para amostras tratadas com $\mathrm{HCl}$ após agitação mecânica.

Na Figura 4.10 pode-se observar uma diminuição considerável no tamanho de partículas devido ao tratamento ácido e à agitação mecânica, a argila sem tratamento apresenta um diâmetro médio de partícula de 101,8 $\mu \mathrm{m}$, já a amostra submetida ao tratamento com solução $2 \mathrm{M}$ de $\mathrm{HCl}$ por 5 horas apresenta um diâmetro médio $77,5 \mu \mathrm{m}$, após a agitação mecânica o diâmetro médio das partículas apresenta o valor de $32,9 \mu \mathrm{m}$.

\subsubsection{Comparação das distribuições granulométricas das amostras após tratamento e agitação mecânica}

Com o propósito de estimar o efeito causado pelos tratamentos utilizados, foram comparadas as curvas de distribuição granulométrica das amostras tratadas e lavadas junto com a prova em branco. A Figura 4.11 mostra as curvas de distribuição granulométrica das amostras tratadas com $\mathrm{LiCl}, \mathrm{NaCl}$ e $\mathrm{HCl}$. 


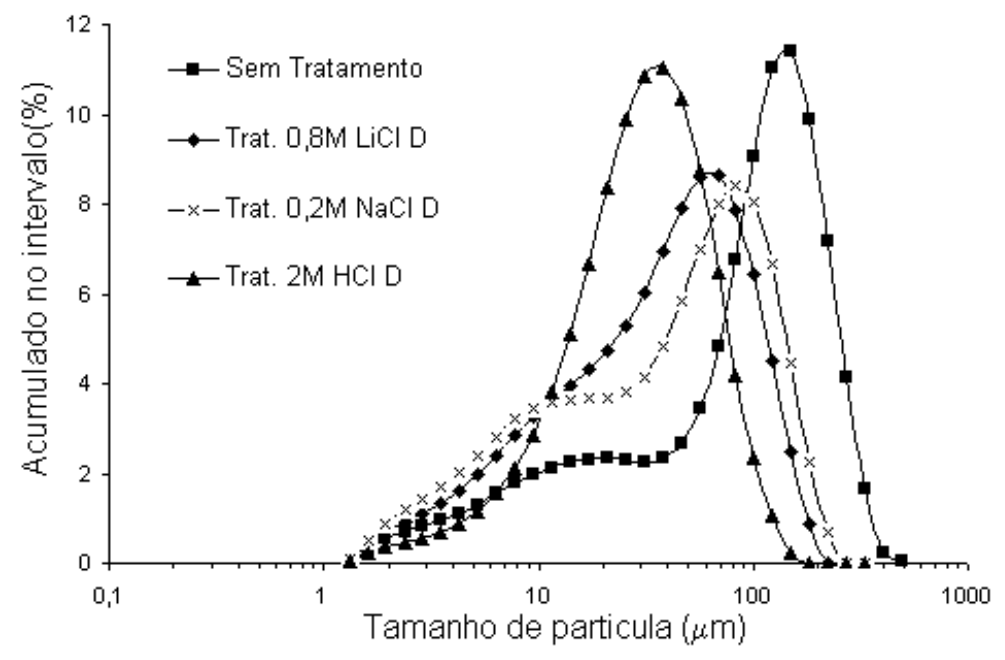

Figura 4.11: Curvas de distribuição granulométrica das amostras tratadas com $\mathrm{LiCl}, \mathrm{NaCl}$ e $\mathrm{HCl}$.

Os resultados evidenciam que todos os tratamentos estudados conduzem à desaglomeração das partículas de vermiculita em diferentes níveis. Isto pode ser observado no deslocamento para esquerda da curva de distribuição de tamanho de partícula. As amostras tratadas com sais inorgânicos apresentaram menor diminuição no tamanho de partícula em comparação com as amostras tratadas com $\mathrm{HCl}$, os diâmetros médios foram $85,7 \mu \mathrm{m}$ e $94,4 \mu \mathrm{m}$ para as amostras tratadas com $\mathrm{LiCl}$ e $\mathrm{NaCl}$, respectivamente. Já as amostras tratadas com $\mathrm{HCl}$ apresentaram um diâmetro médio de partícula de $32,9 \mu \mathrm{m}$, conduzindo á interpretação de que o tratamento com ácido clorídrico leva a condições favoráveis à desaglomeração (ou talvez delaminação) das partículas de vermiculita. Além disso o tratamento ácido modifica a superfície da argila gerando uma maior quantidade de grupos $\mathrm{OH}^{-}$na superfície que permitem a intercalação de moléculas orgânicas polares, por interação dipolo/dipolo, ou por ligação de hidrogênio.

\subsection{Avaliação dos compósitos}

Com o objetivo de avaliar a influência da adição de vermiculita tratada na matriz de PP foram preparados compósitos polipropileno/vermiculita. Para este propósito, foram escolhidas as amostras de vermiculita tratadas com soluções $2 \mathrm{M}$ de $\mathrm{HCl}$ por um período de 5 horas, isto devido a que ditas amostras apresentaram fortes quedas na CTC, atingindo valores semelhantes às das esmectitas, bem como os maiores inchamentos e os menores diâmetros médios de partícula após a agitação mecânica. Na Figura 4.12 mostra-se os pellets dos compósitos preparados no reômetro de 
torque (misturardor) Haake, das amostras de vermiculita sem tratar e tratada acidamente correspondentes as formulações PP/PP-g-AM/10\%VMTST e PP/PP-gAM/10\%VMTCT respectivamente.

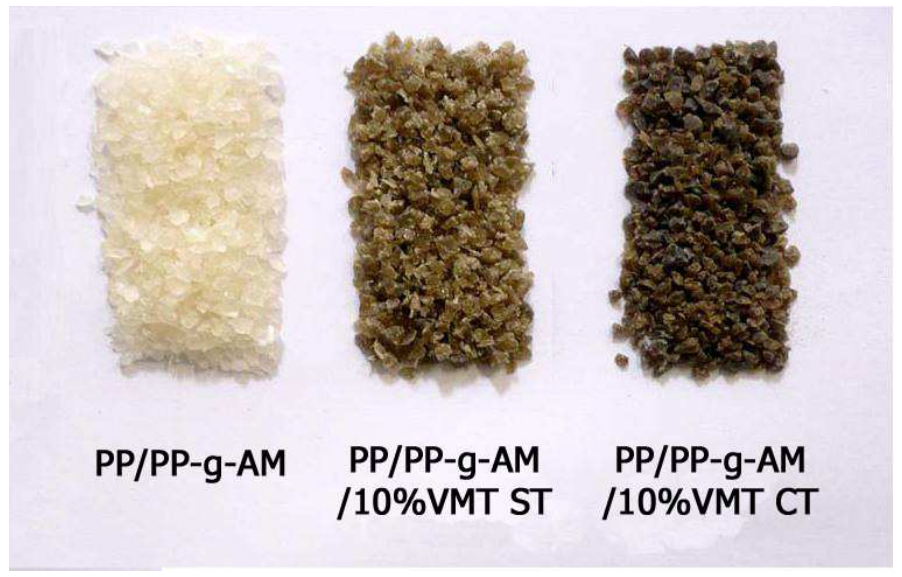

Figura 4.12: Foto dos grânulos ou pellets dos compósitos PP/vermiculita.

Na Figura 4.12 pode-se observar que as amostras que contêm vermiculita sem tratar e tratada acidamente exibem um forte amarelamento comparadas com as amostras sem conteúdo de vermiculita. Este fenômeno indicaria que o PP sofreu degradação oxidativa durante o processamento provavelmente devido à presença de água ou das hidroxilas presentes na estrutura da vermiculita. Outro fator que poderia ter contribuído ao processo de oxidação do PP é a quantidade considerável de $\mathrm{Fe}^{+3}$ presente na vermiculita utilizada, pois é sabido que la presença de íons metálicos pode contribuir ao processo de oxidação dos polímeros, afetando suas propriedades a longo prazo (GORGHIU et al., 2004; VERDU, 2001).

Na mesma Figura 4.12 observa-se também que a amostra que contém vermiculita tratada acidamente exibe o maior escurecimento. Esta mudança na cor indicaria um alto nível de degradação do PP e a conseqüente perda de propriedades mecânicas (impacto, tração, alongamento, etc.). Esta degradação poderia ser atribuída à formação de sítios ácidos nas camadas de vermiculita gerados pelo tratamento ácido com $\mathrm{HCl}$, pois como é sabido, modificações químicas tais como ativação ácida e pilarização, alteram a estrutura da argila e consequentemente a acidez (NARAYANAN; DESHPANDE, 2000). A presença destes sítios ácidos podem contribuir à formação de radicais livres acelerando assim o processo de degradação oxidativa do polímero. Outro fator que pode ter contribuído ao processo de degradação é a presença residual de $\mathrm{HCl}$ da solução de tratamento, pois embora tenha sido feito um controle dos íons cloro na lavagem das amostras utilizando uma solução de $\mathrm{AgNO}_{3}$, é possível que teores muito baixos de íons cloro não possam ser detectados pelo método empregado. 


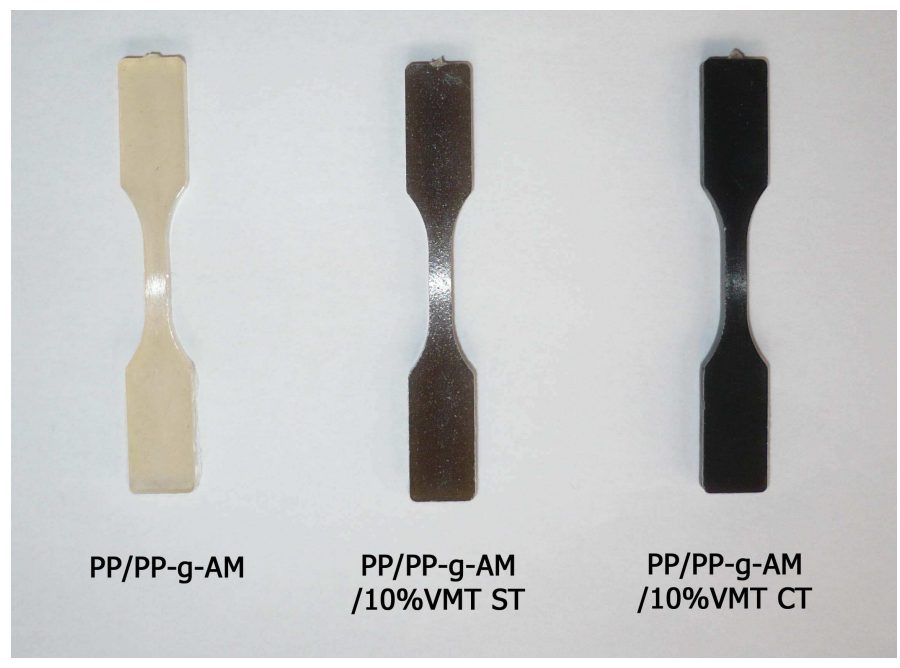

Figura 4.13: Foto dos corpos de prova dos compósitos PP/vermiculita.

Os corpos de prova mostrados na Figura 4.13 apresentaram um maior escurecimento como resultado do processo de injeção. Além disso, foram observados pequenos defeitos como bolhas na parte central dos corpos de prova. Os corpos de prova contendo vermiculita tratada acidamente apresentaram um comportamento frágil, comprovando a ocorrência do processo de degradação no PP. Por outro lado, apesar dos corpos de prova contendo vermiculita contendo vermiculita sem tratamento não terem exibido um comportamento frágil, não foi possível determinar suas propriedades mecânicas devido à expressiva presença de defeitos nos corpos de prova.

Na Figura 4.14 e Figura 4.15 são exibidas as micrografias ópticas dos compósitos contendo vermiculita não tratada e tratada, correspondentes as amostras PP/PP-gAM/10\%VMTST e PP/PP-g-AM/10\%VMTCT respectivamente. Pode-se observar em ambas figuras a presença de partículas claras e escuras dispersas na matriz. As partículas claras correspondem às partículas de vermiculita que apresentaram maior desaglomeração enquanto que as partículas escuras correspondem às partículas que apresentaram pouca desaglomeração ou que sofreram aglomeração. Observa-se também a presença de partículas finas que estão abaixo da faixa de granulometria utilizada no trabalho (entre 63 e $150 \mu \mathrm{m}$ ). Essas partículas são provavelmente, partículas menores de vermiculita que ficaram aderiras à superfície das partículas maiores durante o processo de peneiramento a seco. 


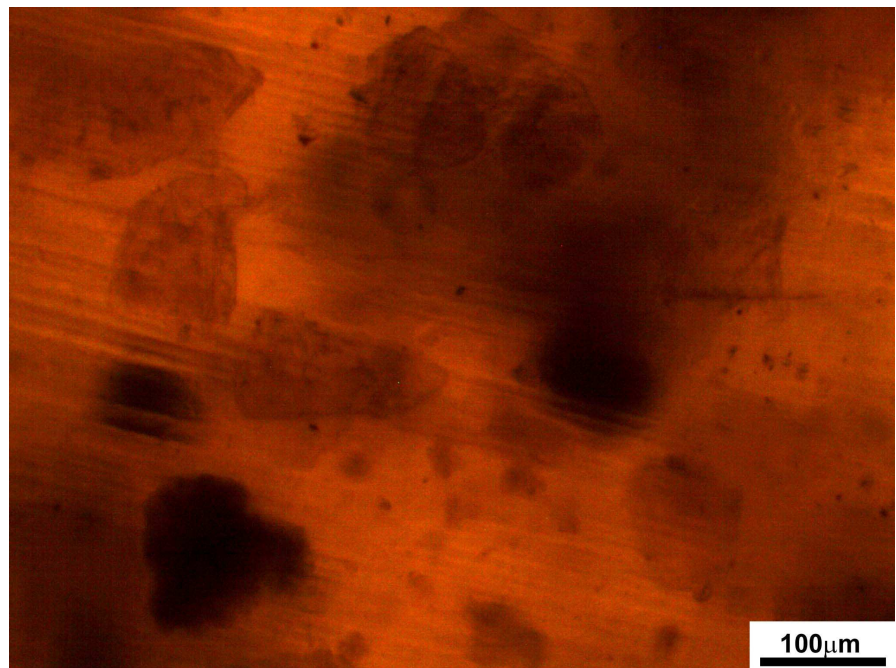

Figura 4.14: Micrografia das partículas de vermiculita sem tratar na matriz de PP.

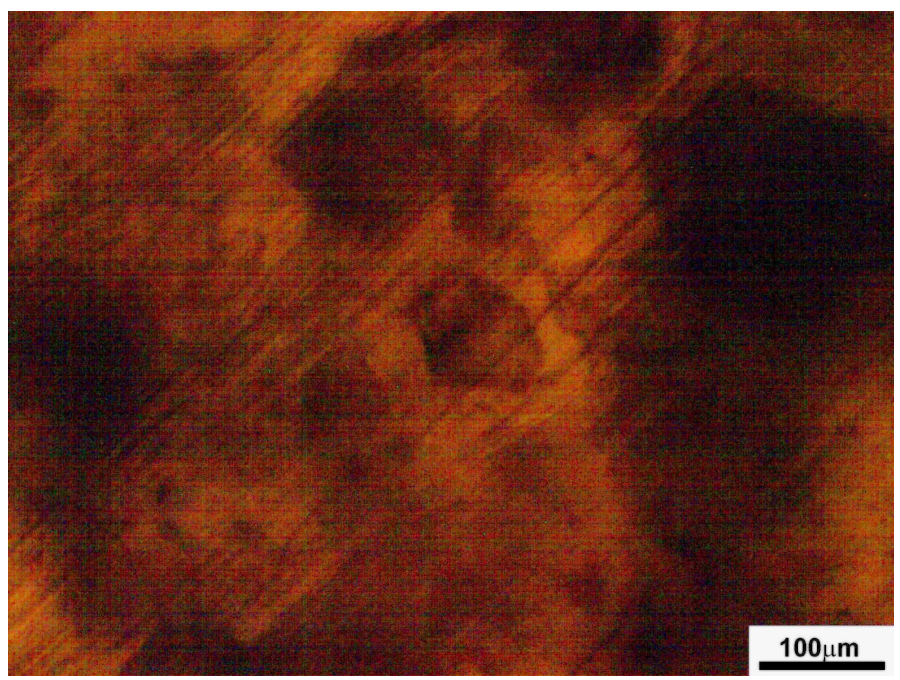

Figura 4.15: Micrografia das partículas de vermiculita tratada acidamente na matriz de PP.

As Figura 4.16 e Figura 4.17 mostram micrografias das amostras de compósitos contendo vermiculita tratada e não tratada respectivamente. Na amostra contendo vermiculita tratada é possível observar uma maior quantidade de partículas dispersas na matriz do que na amostra sem tratamento, o que sugere que o tratamento ácido conduz a uma maior desaglomeração das partículas de vermiculita. No entanto, observa-se também partículas escuras de morfologia irregular com tamanhos acima da faixa da granulometria empregada no trabalho. Estas partículas indicariam a formação de aglomerados devido ao menor tamanho dessas, uma vez que partículas mais finas tem maior tendência formar aglomerados devido a sua alta energia superficial. 


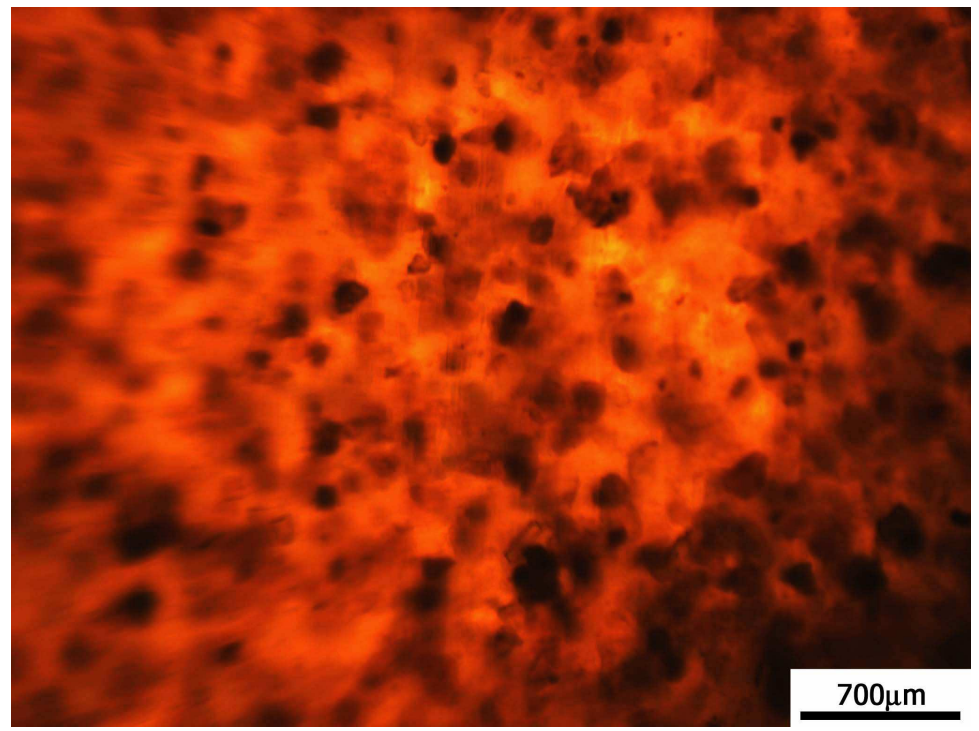

Figura 4.16: Micrografia do compósitos contendo vermiculita sem tratar.

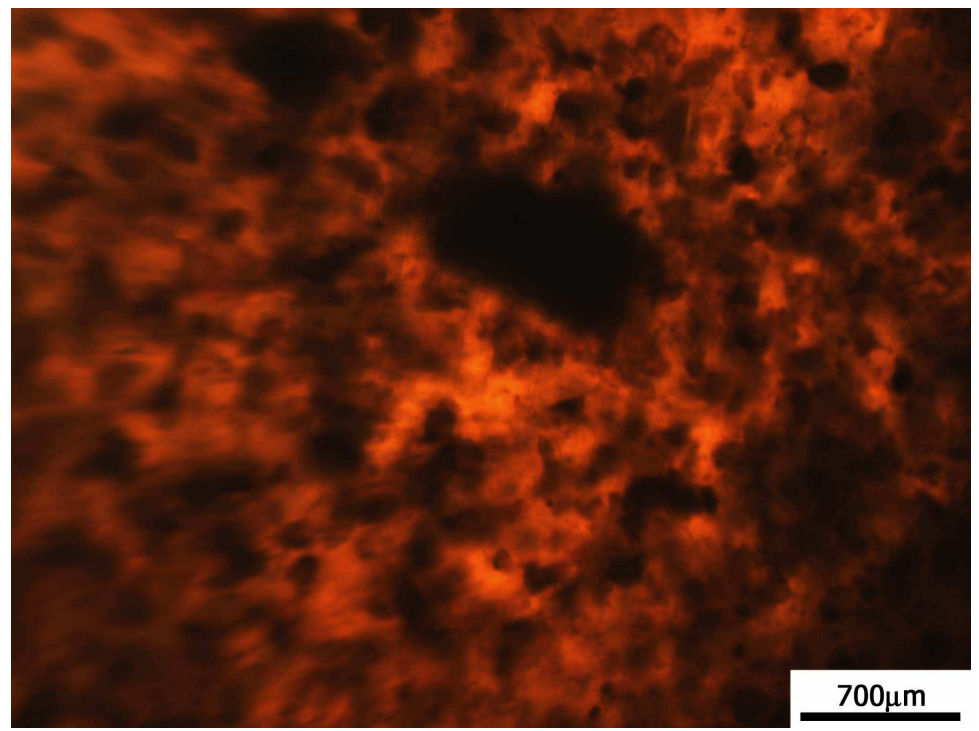

Figura 4.17: Micrografia do compósitos contendo vermiculita tratada acidamente.

Os resultados apresentados e discutidos neste capítulo mostram que, apesar de os tratamentos com os sais de cloretos terem resultado em alguma desaglomeração das partículas de vermiculita, o tratamento com soluções $2 \mathrm{M}$ de $\mathrm{HCl}$ por um período de 5 horas foi efetivamente o tratamento que levou à maior desaglomeração das partículas de vermiculita. No entanto, é necessário realizar um controle mais cuidadoso do pH dessas amostras para evitar que elas causem degradação da matriz polimérica. Outra abordagem que poderia ser utilizada para evitar a degradação da matriz polimérica seria a funcionalização da vermiculita tratada acidamente com anidrido maléico antes do processamento de incorporação na matriz polimérica, como é descrito no 
trabalho de Tjong, Meng e Xu (2002b). Esta abordagem não foi investigada neste trabalho por envolver etapas adicionais de processamento e consequente aumento do custo de obtenção da carga. Contudo, apesar da provável ocorrência de degradação na matriz de PP, os resultados obtidos no presente trabalho indicam a possibilidade de utilizar o tratamento ácido para a desaglomeração de vermiculita bruta, no sentido da produção de altos valores de inchamento, desse modo aumentando as presentes possibilidades de uso industrial desse argilomineral. 


\section{CONCLUSÕES}

- Os tratamentos químicos investigados neste trabalho produziram alterações em diferentes níveis no inchamento e na distribuição de tamanho de partícula da vermiculita do Piauí. Os maiores inchamentos antes da agitação mecânica intensa foram observados nas amostras submetidas a tratamentos com soluções 0,8M de $\mathrm{LiCl}$ sem lavagem (4 a 5 vezes maior do que a prova em branco). Após agitação mecânica, os maiores inchamentos foram observados nas amostras tratadas com soluções $2 \mathrm{M}$ de $\mathrm{HCl}$ por 5 horas (11 vezes maior que o da prova em branco). No entanto, após a secagem das mesmas não foi possível atingirse os mesmos valores de inchamento, registrando valores ao redor de 3 vezes aquele obtido para a prova em branco.

- Tratamentos com $\mathrm{NaCl}$ e $\mathrm{LiCl}$ não exibiram quedas significativas na CTC. Por outro lado, amostras tratadas com soluções 2M de $\mathrm{HCl}$ mostraram importantes quedas nos valores de CTC com o aumento do tempo de tratamento. A diminuição mais importante no tamanho médio dos aglomerados foi observada nas amostras tratadas com soluções $2 \mathrm{M}$ de ácido clorídrico durante 5 horas.

- Dentre os tratamentos estudados, as amostras tratadas com soluções $2 \mathrm{M}$ de $\mathrm{HCl}$ por 5 horas apresentaram as condições mais adequadas para sua incorporação em matriz de polipropileno. Essas amostras exibiram valores de CTC semelhantes àqueles exibidos pelas esmectitas, bem como os maiores valores de inchamento e os menores diâmetro médios de partícula após a agitação mecânica.

- A incorporação de vermiculita tratada acidamente ao polímero (PP), provocou um alto nível de degradação no polímero e consequentemente a perda de propriedades mecânicas (impacto, tração, alongamento, etc.). Esta degradação pode ser atribuída à formação de sítios ácidos na estrutura das partículas de vermiculita gerados pelo tratamento ácido com $\mathrm{HCl}$, bem como à presença residual de $\mathrm{HCl}$ da solução de tratamento. Contudo, as partículas de vermiculita tratada acidamente apresentaram um maior grau de desaglomeração na matriz de PP do que as partículas de vermiculita que não sofreram tratamento. 


\section{Anexo A - Determinação da troca de cátions pelo método de acetato de amônio}

\section{A.1 Fundamento}

A determinação da troca de cátions pelo método de acetato de amônio ${ }^{\mathrm{b}}$, baseiase no deslocamento dos cátions trocáveis naturais da argila por um cátion índice amônio $\left(\mathrm{NH}_{4}^{+}\right)$utilizando uma solução de acetato de amônio pH 7,0 de volume e concentração conhecida. Para determinação do conteúdo de hidrogênio presente na amostra é utilizado o método de Kjeldahl, procedimento no qual por aquecimento desloca-se a amônia $\left(\mathrm{NH}_{3}\right)$, então é recolhida em uma solução ácida com solução indicadora, e finalmente a quantidade de amônio é determinada por titulação com solução padrão ácida.

\section{A.2 Material e reagentes}

Aparelho destilador de kjeldahl, centrifuga de laboratório, balança analítica, agitador magnético, erlenmeyers de 250 e $500 \mathrm{~mL}$, proveta, bureta de 25 ou $50 \mathrm{~mL}$, Almofariz e pistilo, acetato de amônio 3M, hidróxido de sódio a $50 \%$, solução de ácido bórico a $4 \%$ com indicador (vermelho de metila + verde de bromocresol), solução de ácido clorídrico a 0,1N, fenolftaleína e água deionizada .

\footnotetext{
${ }^{\mathrm{b}} \mathrm{O}$ presente anexo é uma recopilação do procedimento utilizado em trabalhos de diferentes autores (ROSENBURG, 1972; BURT, 2004; BOTELHO, 2006)
} 


\section{A.3 Procedimento}

Pesar 5,0 gramas da argila, em seguida colocar a amostra num erlenmeyer de 500mL. Adicionar $200 \mathrm{~mL}$ de acetato de amônio 3M e deixar no agitador magnético durante 15 horas. Após a agitação, colocar a suspensão de argila com acetato de amônio em tubos de ensaios contendo $40 \mathrm{~mL}$ e realizar a centrifugação numa velocidade de 3000 rpm durante 3 minutos para depois fazer a coleta do sobrenadante (solução de acetato de amônio contendo os cátions trocados da amostra), uma vez recolhido o sobrenadante lavar a amostra adicionando etanol e centrifugando novamente, após lavagem levar o material decantado à estufa para secar na temperatura de $60^{\circ} \mathrm{C}$ por 24 horas.

\section{A.3.1 Determinação do amônio}

Desaglomerar o material que foi seco a $60^{\circ} \mathrm{C}$ e pesar 1,5 gramas, transferir o material a uma proveta, adicionar $50 \mathrm{~mL}$ de água deionizada e três gotas de fenolftaleína, colocar a proveta no aparelho destilador de nitrogênio.

Adicionar $\mathrm{NaOH}$ a $50 \%$ até que a solução contida na proveta se torne rósea, garantindo um ligeiro excesso de base, em seguida, injetar vapor no tubo com a finalidade de produzir a liberação da amônia, finalmente a $\mathrm{NH}_{3}$ desprendida é condensada e recebida em um erlenmeyer contendo $50 \mathrm{~mL}$ de ácido bórico previamente adaptado ao conjunto de destilação. O tempo de destilação é de aproximadamente 10 minutos, tempo suficiente para que o frasco receptor volume inicial e adquira azul à medida que vai recebendo $\mathrm{NH}_{3}$. Encerrada a destilação, retira-se o erlenmeyer do sistema de destilação e procede-se a titulação da solução com $\mathrm{HCl}$ 0,1N até a viragem do indicador, obtendo-se novamente a cor original rosa. Anota-se então o volume em $\mathrm{mL}$ de $\mathrm{HCl}$ utilizado para a titulação.

\section{A.3.2 Determinação da razão de umidade a $110^{\circ} \mathrm{C}$}

Preparar um prato porta amostras e adicionar 10 a 20 gramas de argila seca no ar, pesar o prato mais a amostra e anotar o peso aproximado até 0,001 g. Colocar a amostra numa estufa fixada em $110 \pm 5^{\circ} \mathrm{C}$ e deixar na estufa a noite toda (12 a 16 h). Após a secagem tirar a amostra da estufa e deixar resfriar sem permitir que a amostra permaneça a temperatura ambiente por mais de 30 minutos antes de realizar a pesagem, finalmente anotar o peso do amostra seca na estufa e descartar o material. 


\section{A.4 Cálculos}

$$
C T C=\frac{N \cdot V_{H C l} \cdot f \cdot 100 \cdot A D / O D}{M}
$$

$A D=$ (peso amostra seca no ar)-(peso do prato)

$O D=\left(\right.$ peso amostra seca a $\left.110^{\circ} \mathrm{C}\right)-($ peso do prato $)$

onde:

$C T C=$ Capacidade de troca catiônica da argila seca a $110^{\circ} \mathrm{C}(\mathrm{meq} / 100 \mathrm{~g})$

$N=$ Normalidade do $\mathrm{HCl}$

$f=$ fator de correção do ácido

$V_{H C l}=$ volume de $\mathrm{HCl}$ gasto na titulação $(\mathrm{mL})$

$M=$ massa da amostra $(\mathrm{g})$

$A D / O D=$ razão de umidade entre amostra seca ao ar e seca a $110{ }^{\circ} \mathrm{C}$ 


\section{Referências}

AHMADI, S. J.; HUANG, Y. D.; LI, W. Review synthetic routes, properties and future applications of polymer-layered silicate nanocomposites. Journal of Materials Science, v. 39, p. 1919-1925, 2004.

ALEXANDRE, M.; DUBOIS, P. Polymer-layered silicate nanocomposites: preparation, properties and uses of a new class of materials. Materials Science and Engineering, v. 28, p. 1-63, 2000.

BERGAYA, F.; LAGALY, G.; M., V. Handbook of clay science. : Elsevier, 2006. 979-1001 p.

BERGAYA, F.; THENG, B. K.; LAGALY, G. Handbook of clay science. : Elsevier, 2006.

BOTELHO, K. T. sintese de argilas organofílicas e sua incorporação em polimerização in situ para a obtenção de nanocompósitos antichamas de poliestireno. Dissertação (Mestrado) - Departamento de Engenharia Química e Engenharia de Alimentos, Universidade Federal de Santa Catarina, 2006.

BRONDSTED, P.; LILHOLT, H.; LYSTRUP, A. Composite materials for wind power turbine blades. Annu. Rev. Mater. Res., v. 35, p. 505-538, 2005.

BRYDSON, J. A. Plastics materials. 6th ed. ed. : Butterworth-Heinemann, 1995.

BURNSIDE, S. D.; WANG, H. C.; GIANNELIS, E. P. Direct polymer intercalation in single crystal vermiculite. Chemistry of materials, v. 11, p. 1055-1060, 1999.

BURT, R. soil survey laboratory methods manual. 2004.

CABALlERO, F. del R. P.; PONCELET, G. Microporous 18a al-pillared vermiculites: preparation and characterization. Microporous and Mesoporous Materials, v. 37, p. 313-327, 2000.

CALLEGARI, L. O mercado do Plástico. : Gazeta Mercantil, 2000.

CALLISTER, W. D. Materials science and engineering : an introduction. 1991.

CAVALCANTI, E. E. N. Anuário mineral brasileiro Parte III Estatística por Substâncias. : Departamento Nacional de Produção Mineral - DNPM, 2005.

CAVALCANTI, E. E. N. Anuário mineral brasileiro Parte III Estatística por Substâncias. : Departamento Nacional de Produção Mineral - DNPM, 2006.

CAVALCANTI, E. E. N. Sumário Mineral Brasileiro. : Departamento Nacional de Produção Mineral - DNPM, 2007. 
CHAUDHARY, D. S.; JOLLANDS, M.; CSER, F. Understanding rice hull as fillers in polymers : A review. Silicon Chemistry, v. 1, p. 281-289, 2002.

CHO, J.; PAUL, D. Nylon 6 nanocomposites by melt compounding. Polymer, v. 42, p. 1083-1094, 2001.

CHUI, Q. S. H. Contribuicao ao estudo da vermiculita como concentradora de cations : Queenie Siu Hang Chui. Tese (Doutorado) - Instituto de Quimica, Universidade de Sao Paulo, 1998.

CHUI, Q. S. H. Uso de vermiculita massapé paulistana como adsorvedora de metais. Eng. sanit. ambient., v. 10, p. 58-63, 2005.

DENNIS, H.; HUNTER, D. L.; CHANG, D.; KIM, S.; WHITE, J. L.; CHO, J. W.; PAUL, D. Effect of melt processing conditions on the extent of exfoliation in organoclay-based nanocomposites. Polymer, v. 42, p. 9513-9522, 2001.

DÁNYÁDI, L.; JANECSKA, T.; SZABO, Z.; NAGY, G.; MÓCZÓ, J.; PUKáNSZKY, B. Wood flour filled pp composites: Compatibilization and adhesion. Composites Science and Technology, v. 67, p. 2838-2846, 2007.

EBEWELE, R. O. Polymer science and technology. : Boca Raton; London, 2000.

ESTEVES, A. C. C.; BARROS-TIMMONS, A.; TRINDADE, T. Nanocompósitos de matriz polimérica: Estratégias de síntese de materiais hídridos. Quim. Nova, v. 27, n. 5 , p. $798-806,2004$.

FORNES, T.; YOON, P. J.; KESKKULA, H.; PAUL, D. R. Nylon 6 nanocomposites: the effect of matrix molecular weight. Polymer, v. 42, p. 9929-9940, 2001.

FOSTER, M. D. Geochemical studies of clay minerals ii. relation between ionic substitution and swelling in montmorillonites. American Mineralogist, v. 38, n. 1, p. 994-1006, 1953.

FRANÇA, S.; LUZ, A. Utilização da vermiculita como adsorvente de compostos orgânicos poluentes da indústria do petróleo. In: XIX ENTMME Recife, Pernambuco. 2002.

GARCíA-LóPEZ, D.; GOBERNADO-MITRE, I.; MERINO, J.; PASTOR, J. Effect of the amount and functionalization grade of ppgma compatibilization agent in polypropylene/clay nanocomposites. Polymer bulletin, v. 59, p. 667-676, 2007.

GARCÍA-LÓPEZ, D.; PICAZO, O.; MERINO, J.; PASTOR, J. Polypropylene clay nanocomposites: effect of compatibilizing agents on clay dispersion. European Polymer Journal, v. 39, p. 945-950, 2003.

GARRETT, W. G.; WALKER, G. F. Swelling of some vermiculite-organic complexes in water. Clays and Clay Minerals, v. 9, n. 1, p. 557-567, 1962.

GIANNELIS, E. P. Polymer layered silicate nanocomposites. Adv. Mater., v. 8, n. 1, p. 29-35, 1996.

GIORDANO, M.; IANNACE, S.; NICOLAIS, L. European White Book on fundamental research in materials science. : Max - Planck - Gesellschaft, 2001. 
GORGHIU, L.; JIPA, S.; ZAHARESCU, T.; SETNESCU, R.; MIHALCEA, I. The effect of metals on thermal degradation of polyethylenes. Polymer Degradation and Stability, v. 84, p. 7-11, 2004.

GRIM, R. E. Clay Mineralogy. 1968.

HARO, M. C. J. de; MAQUEDA, L. A. P.; STEPKOWSKA, E. T.; MARTíneZ, J. M.; PÉREZ-RODRÍGUEZ, J. L. the influence of exchange cation on thermal behaviour of ground vermiculite. Journal of Thermal Analysis and Calorimetry, v. 71, p. 761-771, 2003.

HARPER, C. A. Handbook of plastics, elastomers, and composites. : New York : McGraw-Hill, 2002.

HART, M. P.; BROWN, D. R. Surface acidities and catalytic activities of acid-activated clays. Journal of Molecular Catalysis A: Chemical, v. 212, n. 1-2, p. 315-321, 2004.

HASEGAWA, N.; KAWASUMI, M.; KATO, M.; USUKI, A.; OKADA, A. Preparation and mechanical properties of polypropylene - clay hybrids using a maleic anhydride-modified polypropylene oligomer. Journal of Applied Polymer Science, v. 67, p. 87-92, 1998.

HUSSAIN, F.; HOJJATI, M.; OKAMOTO, M.; GORGA, R. E. Review article: Polymer-matrix nanocomposites, processing, manufacturing, and application: An overview. Journal of composite materials, v. 40, n. 17, p. 1511-1575, 2006.

JINNAI, H.; SMALLEY, M. V.; HASHIMOTO, T. Neutron scattering study of vermiculite-poly(vinyl methyl ether) mixtures. Langmuir, v. 12, p. 1199-1203, 1996.

KARASEK, L.; SUMITA, M. Review characterization of dispersion state of filler and polymer-filler interactions in rubber-carbon black composites. Journal of Materials Science, v. 31, n. 2, p. 281 289, 1996.

KAWASUMI, M.; HASEGAWA, N.; KATO, M.; USUKI, A.; OKADA, A. Preparation and mechanical properties of polypropylene - clay hybrids. Macromolecu, v. 30, p. 6333-6338, 1997.

KOLMER, H.; KUHNEL, R. Spatial distribution of particles in coatings of paper and fillers in plastics. Applied Clay Science, v. 5, p. 325-338, 1990.

KRISTKOVA, M.; WEISS, Z.; FILIP, P. Hydration properties of vermiculite in phenolic resin friction composites. Applied Clay Science, v. 25, p. 229-236, 2004.

LAIRD, D. A. Influence of layer charge on swelling of smectites. Applied Clay Science, v. 34, p. 74-87, 2006.

LIPATOV, Y. S. Polymer Reinforcement. : ChemTec Publishing, 1994.

LIU, B.; DING, Q.; ZHANG, J.; HU, B. Preparation and properties of new epdm/vermiculite nanocomposites. Polymer Composites, v. 26, n. 5, p. 706-712, 2005 . 
LIU, D.; DU, X.; MENG, Y. Facile synthesis of exfoliated polyaniline/vermiculite nanocomposites. Materials letters, v. 60, n. 15, p. 1847-1850, 2006.

LONKAR, S. P.; THERIAS, S. M.; CAPERAA, N.; LEROUX, F.; GARDETTE, J.; SINGH, R. Preparation and nonisothermal crystallization behavior of polypropylene/layered double hydroxide nanocomposites. Polymer, v. 50, p. 1505-1515, 2009.

LOZANO, K.; BARRERA, E. Nanofiber-reinforced thermoplastic composites. thermo analytical and mechanical analyses. Journal of Applied Polymer Science, v. 79 , p. $125-133,2001$.

MAJEWSKI, P.; CHOUDHURY, N. R.; SPORI, D.; WOHLFAHRT, E.; WOHLSCHLOEGEL, M. Synthesis and characterisation of star polymer/silicon carbide nanocomposites. Materials Science and Engineering A, v. 434, p. 360-364, 2006.

MAQUEDA, C.; PEREZ-RODRIGUEZ, J. L.; SUBRT, J.; MURAFA, N. Study of ground and unground leached vermiculite. Applied Clay Science, v. 44, p. 178-184, 2009 .

MARCOS, C.; ARANGO, Y.; RODRIGUEZ, I. X-ray diffraction studies of the thermal behaviour of commercial vermiculites. Applied Clay Science, v. 42, p. 368-378, 2009.

MARTINS, J. Processo aperfeiçoado de hidrofobização de vermiculita expandida. BR, PI 900405, p. 25 fev., 1991.

MARTYNKOVA, G. S. G. S.; VALASKOVA, M.; SUPOVA, M. Organo-vermiculite structure ordering after pvac introduction. physica status solidi (a), v. 204, n. 6, p. 1870-1875, 2007.

MATTHEWS, F.; RAWLINGS, R. Composite materials: engineering and science. : woodhead publishing limited, 1999.

MICHOT, L. J.; VILLIÉRAS, F.; FRANÇOIS, M.; BIHANNIC, I.; CASES, M. P. . J. M. Water organisation at the solid aqueous solution interface. C. R. Geoscience, v. 334, p. 611-631, 2002.

NAMBOOTHIRY, M. A.; ZIMMERMAN, T.; COLDREN, F. M.; LIU, J.; KIM, K.; CARROLL, D. L. Electrochromic properties of conducting polymer metal nanoparticles composites. Synthetic Metals, v. 157, p. 580-584, 2007.

NARAYANAN, S.; DESHPANDE, K. Aniline alkylation over solid acid catalysts. Applied Catalysis A, v. 199, p. 1-31, 2000.

NORRISH, K. the swelling of montmorillonite. 1954.

OKADA, A.; USUKI, A. The chemistry of polymer-clay hybrids. Materials Science and Engineering: C 3, p. 109-115, 1995.

OKADA, A.; USUKI, A. Twenty years of polymer-clay nanocomposites. Macromolecular Materials and Engineering, v. 291, p. 1449 - 1476, 2006. 
OSMAN, M. A. organo-vermiculites : synthesis, structure and properties, platelike nanoparticles with high aspect ratio. journal of materials chemistry, v. 16, p. 3007-3013, 2006.

PADILHA, A. F. matriales de engenharia: Microestrutura, Propriedades. : Hemus Editora Ltda, 1997.

PEIJS, T. Composites for recyclability. Materials Today, v. 6, p. 30-35, 2003.

PEREIRA, D. de S. Propriedades de materiais nanoestruturados do sistema epoxídico DGEBA/TETA modificado com um éster de silsesquioxano. Dissertação (Mestrado) — Fisica da matéria condensada, Universidade Estadual Paulista, 2006.

PINTO, C. H. C. Vermiculita Hidrofobizada como agente adsorvente de óleo em águas. Dissertação (Mestrado) — PPGEQ - UFRN, 1994.

POTTER, M. J. Vermiculite. U.S. Geological Survey, Mineral Commodity Summaries. 2008. 186-187 p. Disponível em: <http://minerals.usgs.gov/minerals/pubs/mcs/2008/mcs2008.pdf > .

RAY, S. S.; OKAMOTO, M. Polymer/layered silicate nanocomposites: a review from preparation to processing. Progress in polymer science, v. 28, n. 11, p. 1539-1641, 2003.

REIS, E. Levantamento da situação e das carências tecnológicas dos minerais industriais brasileiros com enfoque na mineração de: Argila para cerâmica, barita, bentonita, caulim para carga, talco / agalmatolito e vermiculita. Ministério de Ciência e Tecnologia, 2001. Disponível em: $<$ http://www.cgee.org.br/prospeccao/doc_arq/prod/registro/pdf/regdoc710.pdf $>$.

RESEARCH; MARKETS. China Polypropylene (PP) Market Report, 2007-2008. 2008.

RISTOLAINEN, N.; VAINIO, U.; PAAVOLA, S.; TORKKELI, M.; SERIMAA, R.; SEPPALA, J. Polypropylene/organoclay nanocomposites compatibilized with hydroxyl-functional polypropylenes. Journal of Polymer Science: Part B: Polymer Physic, v. 43, p. 1892-1903, 2005.

RITTLER, H. L. Method of treating phyllosilicates. US, v. 4,952,388, p. 28 Ago., 1990.

ROSENBURG, J. P. Estudo de vermiculitas brasileiras. Tese (Doutorado) Instituto de Quimica, Universidade de Sao Paulo, 1972.

RUIZ-HITZKY, E.; MEERBEEK, A. V. Handbook of clay science. : Elsevier, 2006. 583-621 p.

SAHEB, D. N.; JOG, J. P. Natural fiber polymer composites: A review. Advances in Polymer Technology, v. 18, p. 351-363, 1999.

SANTOS, A. C. V. dos. Uso de técnicas eletroanalíticas em fluxo no estudo da adsorção de $C d(I I), P b(I I)$ e Cu(II) em vermiculita visando tratamento alternativo para efluentes da indústria de tintas. Dissertação (Mestrado) - Instituto de Química, Universidade de São Paulo, 2006. 
SANTOS, C. P. F.; MELO, D. M. A.; MELO, M. A. F.; SOBRINHO, E. V. Caracterização e usos de argilas bentonitas e vermiculitas para adsorção de cobre (ii) em solução. Cerâmica, v. 48, p. 178-182, 2002.

SARANTÓPOUlOS, C. I. G. L.; OLIVEIRA, L. M. d.; PADUlA, M.; COLTRO, L.; ALVES, R. M. V.; GARCIA, E. E. C. Embalagens Plásticas Flexíveis : Principais Polímeros e Avaliação de Propriedades. : CETEA/ITAL, 2002.

SATO, K. The mechanical properties of filled polymers. Progress in Organic Coatings, v. 4, p. $271-302,1976$.

SHAO, W.; WANG, Q. Partial exfoliation and layer expansion of vermiculite layer in solid state by solid state shear milling (s3m) method. Journal of Applied Polymer Science, v. 101, n. 3, p. 1806-1809, 2006.

SHAO, W.; WANG, Q.; CHEN, Y.; GU, Y. Preparation and properties of polypropylene/vermiculite nanocomposite through solid-state shear compounding (s3c) method using pan-mill equipment. Journal Materials and Manufacturing Processes, v. 21, n. 2, p. 173-179, 2006.

SHAO, W.; WANG, Q.; MA, H. Study of polypropylene/montmorillonite nanocomposites prepared by solid-state shear compounding (s3c) using pan-mill equipment: the morphology of montmorillonite and thermal properties of the nanocomposites. Polymer International, v. 54, p. 336-341, 2005.

SHINZATO, M. C. estudo experimeltal de retenção de íons metálicos em vermiculita. Dissertação (Mestrado) - Instituto de Geociências, Universidade de São Paulo, 1995.

SONMEZ, F. O.; AKBULUT, M. Process optimization of tape placement for thermoplastic composite. Composites. Part A, Applied science and manufacturing, v. 38 , p. $2013-2023,2007$.

SOUZA-SANTOS, P. Ciência e tecnologia de argilas vol 1. : Ed. Blucher Ltda., 1975 .

SOUZA-SANTOS, P. Ciência e tecnologia de argilas vol2. : Ed. Blucher Ltda., 1975 .

SOUZA-SANTOS, P.; RIEGO, A. R. Effect of lithium treatment on the bulk densities of exfoliated vermiculite. In: International Clay Conference 1981. Proceedings of the Seventh International Clay Conference held in Bologna and Pavia, Italy, September 6-12, 1981. Developments in Sedimentology no. 35. : Elsevier, Amsterdam, 1982.

SUQUET, H.; FRANCK, R.; LAMBERT, J. F.; ELSASS, F.; MARCILLY, C.; CHEVALIER, S. Catalytic properties of two pre-cracking matrices: a leached vermiculite and a al-pillared saponite. Applied Clay Science, v. 8, 5, p. 349-364, 1994.

TJONG, S.; BAO, S. Crystallization regime characteristics of exfoliated polyethylene/ vermiculite nanocomposites. Journal of Polymer Science, Part B: Polymer Physics, v. 43, n. 3, p. 253 - 263, 2005. 
TJONG, S.; MENG, Y. Preparation and characterization of melt-compounded polyethylene/vermiculite nanocomposites. Journal of Polymer Science, Part B: Polymer Physics, v. 41, n. 13, p. 1476 - 1484, 2003.

TJONG, S.; MENG, Y.; HAY, A. Novel preparation and properties of polypropylene-vermiculite nanocomposites. Chemistry of Materials, v. 14, n. 1, p. 44-51, 2002.

TJONG, S.; MENG, Y.; XU, Y. Preparation and properties of polyamide 6/polypropylene-vermiculite nanocomposite/polyamide 6 alloys. Journal of Applied Polymer Science, v. 86, n. 9, p. 2330 - 2337, 2002.

TJONG, S.; MENG, Y.; XU, Y. Structure and properties of polyamide$6 /$ vermiculite nanocomposites prepared by direct melt compounding. Journal of Polymer Science, Part B: Polymer Physics, v. 40, n. 24, p. 2860 - 2870, 2002.

TJONG, S. C. Structural and mechanical properties of polymer nanocomposites. Materials Science \& Engineering R-Reports, v. 53(3-4), p. 73-197, 2006.

UGARTE, J. F. O.; SAMPAIO, J. A.; FRANÇA, S. C. A. Rochas $\&$ minerais industriais : usos e especificações. : Rio de Janeiro : CETEM/MCT, 2005. 677-698. p.

UTRACKI, L. clay - containing polymeric nanocomposites. : rapra technology limited, 2004.

VAIA, R. A.; GIANNELIS, E. P. Polymer melt intercalation in organically-modified layered silicates: Model predictions and experiment. Macromolecules, v. 30, p. 8000-8009, 1997.

VALENZUELA-DÍAZ, F. R.; SOUZA-SANTOS, P. studies on the acid activation of brazilian smectitic clays. Quim. Nova, v. 24, n. 3, p. 345-353, 2001.

VASILIEV, V. V.; MOROZOV, E. V. Mechanics and Aanalysis of Composite Materials. : Elsevier Science, 2001.

VERDU, J. Fillers and Filled Polymers. : Wiley-VCH, 2001. 275-280 p.

VIEIRA-COELHO, A. C. Estudo, em escala de laboratorio, do inchamento em água de vermiculitas brasileiras tratadas com soluções salinas inorgânicas. Dissertação (Mestrado) — Escola Politecnica, Universidade de São Paulo, 1986.

VIEIRA, E. V. Insumos Minerais para Perfuração de Poços de Petróleo. : Centro de Tecnologia Mineral Ministério da Ciência e Tecnologia - CETEM, 2004. 62-79 p.

WALKER, G. X-ray identification and crystal structures of clay minerals, cap VII. 1961. 297 p.

WALKER, G. F. Macroscopic swelling of vermiculite crystals in water. Nature, v. 187, p. $312-313,1960$.

WARD, W.; GAINES, G.; ALGER, J. M.; STANLEY, T. Gas barrier improvement using vermiculite and mica in polymer films. Journal of Membrane Science, v. 55, p. 173-180, 1991. 
WEISS, R. Fabrication techniques for thermoplastic composites. Cryogenics, v. 31, p. $319-322,1991$.

WU, C. L.; ZHANG, M. Q.; RONG, M. Z.; FRIEDRICH, K. Silica nanoparticles filled polypropylene: effects of particle surface treatment, matrix ductility and particle species on mechanical performance of the composites. Composites Science and Technology, v. 65, p. 635-645, 2005.

XIE, W.; GAO, Z.; PAN, W. P.; HUNTER, D.; SINGH, A.; VAIA, R. Thermal degradation chemistry of alkyl quaternary ammonium montmorillonite. Chem. Mater., v. 13, p. 2979-2990, 2001.

XU, J.; LI, R.; XU, Y.; LI, L.; MENG, Y. Preparation of poly(propylene carbonate)/organo-vermiculite nanocomposites via direct melt intercalation. European Polymer Journal, v. 41, p. 881-888, 2005.

XU, J.; MENG, Y. Z.; LI, R. K. Y.; XU, Y.; RAJULU, A. V. Preparation and properties of poly(vinyl alcohol)-vermiculite nanocomposites. Journal of Polymer Science Part B: Polymer Physics, v. 41, n. 7, p. 749-755, 2003.

XU, W.; LIANG, G.; ZHAI, H.; TANG, S.; HANG, G.; PAN, W. P. Preparation and crystallization behaviour of pp/pp-g-mah/org-mmt nanocomposite. European Polymer Journal, v. 39, p. 1467-1474, 2003. 